\title{
How does personal bankruptcy law affect start-ups?*
}

\author{
Geraldo Cerqueiro \\ Católica Lisbon School of Business and Economics \\ geraldo.cerqueiro@ucp.pt \\ María Fabiana Penas \\ CentER - Tilburg University \\ m.penas@uvt.nl
}

July 2016

\begin{abstract}
We exploit state-level changes in the amount of personal wealth individuals can protect under Chapter 7 to analyze the effect of debtor protection on the financing structure and performance of a representative panel of U.S start-ups. The effect of increasing debtor protection depends on the entrepreneur's level of wealth. Firms owned by mid-wealth entrepreneurs whose assets become fully protected suffer a reduction in credit availability, employment, operating efficiency, and survival rates. We find no such negative effects for low-wealth and high-wealth owners. Our results are consistent with theories that predict that asset protection in bankruptcy leads to a redistribution of credit.
\end{abstract}

(JEL: G32, G33, K35, M13)

Keywords: Debtor Protection, Personal Bankruptcy Law, Start-ups, Bank financing.

\footnotetext{
* We are grateful to Philip Strahan (the Editor) and to two anonymous referees for very helpful comments and suggestions. We also thank Rui Albuquerque, Allen Berger, Neil Bhutta, Fabio Braggion, Martin Brown, Hamid Boustanifar, Fabrice Cavarretta, Ethan Cohen-Cole, Marco Da Rin, Hans Degryse, William Forster, Todd Gormley, Isaac Hacamo, Deepak Hegde, Ulrich Hege, Edith Hotchkiss, Erik Hurst, José Jorge, Leora Klapper, Arthur Korteweg, Ulf von Lilienfeld-Toal, Gustavo Manso, Judit Montoriol-Garriga, Ramana Nanda, Gordon Phillips, E.J. Reedy, Cláudia Ribeiro, Alicia Robb, Kasper Roszbach, Antoinette Schoar, Robert Seamans, Sascha Steffen, André van Stel, Peter Thompson, and participants at the Entrepreneurial Finance and Innovation Conference (Boston), the Western Finance Association Meetings (Santa Fé), the Kauffman-Dallas Fed Conference on Small Business, Entrepreneurship, and Economic Recovery (Atlanta), the International Finance and Banking Society Meetings (Rome), the Financial Intermediation Research Society Meetings (Minneapolis), the Workshop on Entrepreneurship, Innovation and Human Capital (Lisbon), the NBER Entrepreneurship Working Group Meeting (Boston), the Kauffman Firm Survey Workshop (Lausanne), and seminar participants at the Sveriges Riksbank, Faculdade de Economia do Porto, Nova SBE, Universidad Torcuato Di Tella, and Manchester Business School for their valuable comments. The European Investment Bank generously provided financial support through an EIBURS grant. Any opinions, findings, and conclusions or recommendations expressed in this material are those of the authors and do not necessarily reflect the views of the Ewing Marion Kauffman Foundation.
} 


\section{Introduction}

Entrepreneurs require adequate funding in order to run their businesses successfully. An entrepreneur's borrowing capacity depends on the amount of personal wealth that creditors can seize if the entrepreneur fails. Therefore, borrowing capacity depends not only on how much wealth the entrepreneur has, but also on how much of that wealth the entrepreneur is entitled to keep in bankruptcy. A more debtorfriendly bankruptcy regime reduces the amount of assets creditors can seize in bankruptcy, and thereby it could reduce entrepreneurs' access to credit and hurt the performance of their businesses. On the other hand, this wealth insurance could increase entrepreneurs' demand for credit and willingness to invest. How debtor protection affects business ventures is therefore an empirical question.

In this paper we exploit state-level changes in U.S. personal bankruptcy law to study the causal effect of debtor protection on the credit availability, employment, and performance of young firms. We use the Kauffman Firm Survey (KFS), a representative panel of U.S. start-ups that began operations in 2004, and which are followed until 2011. ${ }^{1}$ To quantify the importance of liquidity constraints we analyze the effects of changes in debtor protection on entrepreneurs with different levels of initial wealth.

We examine changes in personal bankruptcy law because it applies directly to all personal liabilities and guarantees of firm owners. Whether a firm owner is liable or not for the firm's debts depends on the legal form of the business organization. In an unlimited liability firm all debts of the firm are personal, since there is no legal distinction between the firm and the owner. If the firm instead has the limited liability

\footnotetext{
${ }^{1}$ Robb and Robinson (2014) use the KFS to study the capital structure choices of start-ups. They find that these young firms rely extensively on bank financing.
} 
form the owner is not liable for the firm's debts. However, almost half of the owners of limited liability firms in our sample report that they borrow at the personal level to finance the firm's operations.

Most individuals in the U.S. file for personal bankruptcy under Chapter 7. Under this Chapter debtors keep their future income, but they must turn over any unsecured assets they own above a predetermined exemption limit. The exemption limit is the maximum amount of the borrower's personal assets that is protected from creditors, and therefore it provides a precise measure of debtor protection.

We exploit the staggered increases in Chapter 7 exemption limits implemented in several U.S. states during our sample period. The panel structure of our data allows us to include firm fixed effects that control for time-invariant differences between entrepreneurs, firms, and states. These firm fixed effects address the concern, among others, that states with high exemption levels might attract less skilled entrepreneurs. To remove the effects of potentially confounding state-level shocks we exploit the differential effects of the exemption laws across entrepreneurs with different levels of personal wealth, as predicted by theory (Lilienfield-Toal and Mookherjee, 2016).

We consider three groups of entrepreneurs according to how much unprotected (or pledgeable) wealth they have: Low wealth, Mid wealth, and High wealth. ${ }^{2}$ Low wealth entrepreneurs have all their wealth already protected under the old exemption limit, and an increase in exemptions should therefore not affect this group directly. Mid wealth entrepreneurs are left without unprotected assets after the increase in the exemption limit. This reduction in pledgeable assets could reduce their

\footnotetext{
${ }^{2}$ We construct the wealth groups using the five net worth ranges provided in the KFS. The Low wealth group includes entrepreneurs with negative or zero net worth and entrepreneurs with net worth lower than $\$ 50,000$. The Mid wealth group includes entrepreneurs with net worth between $\$ 50,000$ and $\$ 250,000$. The High wealth group includes entrepreneurs with net worth of more than $\$ 250,000$. We note that most entrepreneurs in the Low wealth group have no pledgeable wealth, since all states have positive exemption limits at the start of our sample.
} 
access to credit. High wealth entrepreneurs still have substantial pledgeable wealth under the new, higher, exemption limit. For this reason, they should be less affected by the exemptions than the previous group. Some studies have shown that the exemptions could also lead to the redistribution of credit among individuals (Gropp et al. (1997), Lilienfeld-Toal and Mookherjee (2016).

We obtain strong empirical support for these predictions.

First, for entrepreneurs who are left without pledgeable assets (i.e., the Mid wealth group), the increase in exemptions has a strong negative impact on the financing, employment, and performance of their firms. We find that these entrepreneurs permanently reduce the inflow of personal credit they obtain to finance the firm by about $6 \%$ for every $\$ 10,000$ increase in the exemption limit. This effect is economically important, since the median increase in exemptions during our sample period is $\$ 21,400$. The reduction in personal credit is driven by a reduction in both credit card financing and other bank loans. Importantly, as expected, we do not find any effects of the exemptions on the inflow of business credit (i.e., loans obtained in the name of the firm). This important falsification test rules out the possibility that our finding for personal credit might be driven by contemporaneous local economic shocks rather than by the exemption laws. With respect to employment, we find that following an increase in exemptions, firms owned by Mid wealth entrepreneurs become less likely to be employers. In addition, these firms generate fewer revenues, have lower operating efficiency (which we measure as average revenue per employee), and become more likely to fail. These findings indicate that tighter credit 
constraints force these firms to operate at a suboptimal scale, making them more vulnerable to failure. ${ }^{3}$

Second, High wealth entrepreneurs experience an increase in their credit card limits following an increase in exemptions. This result is consistent with the redistribution of credit toward the wealthiest entrepreneurs, as predicted in LilienfeldToal and Mookherjee (2016) and documented in a cross-sectional study of consumer credit by Gropp et al. (1997). However, the increase in the supply of credit to wealthy entrepreneurs does not improve the performance of their firms, suggesting that these entrepreneurs were already operating at their desired scale.

Third, we find that start-ups owned by Low wealth entrepreneurs increase their use of other personal bank loans. Although a higher exemption level does not affect how much pledgeable wealth these entrepreneurs have, it levels the playing field between the Low wealth and Mid wealth entrepreneurs in terms of access to credit opportunities. This finding is consistent with the credit redistribution mechanisms studied in Lilienfeld-Toal and Mookherjee (2016). Furthermore, we document important real effects of the exemptions for Low wealth entrepreneurs: their firms become more likely to hire employees and experience a significant improvement in operating efficiency. These real effects results are thus consistent with the alleviation of credit constraints for these entrepreneurs.

Our paper makes two important contributions to the literature. First, we improve on the empirical identification of the effects of exemptions on bank financing. While earlier studies use cross-sectional variation in exemption levels (Gropp et al., 1997, Berkowitz and White, 2004; Berger et al., 2011), our paper is the first to exploit the effect of state laws that increased exemption levels, allowing us to

\footnotetext{
${ }^{3}$ See, for instance, Holtz-Eakin et al., (1994), Blanchflower and Oswald (1998), Cabral and Mata (2003), Albuquerque and Hopenhayn (2004), and Fracassi et al. (forthcoming).
} 
control for unobserved heterogeneity across entrepreneurs, firms, and states. Our study is thus related to a fast growing literature that studies the causal effect of changes in the financial and regulatory environment on entrepreneurship (Djankov et al., 2002, Cetorelli and Strahan, 2006, Klapper et al., 2006, Bertrand et al., 2007, Kerr and Nanda, 2009, and Hombert et al., 2013). Second, our paper studies the effect of debtor protection not only on start-ups' financing structure, but also on several indicators of real performance, such as employment, operating efficiency, and survival. Our study therefore takes a step forward by analyzing whether credit market frictions triggered by changes in exemptions actually affect young firms' real outcomes. In particular, we focus not only on operating efficiency and probability of survival, but also on the job creation role of existing start-ups (Haltiwanger et al., 2013, Adelino et al., 2014).

Finally, our findings contribute to a broader debate on the role of regulation and institutions in promoting job creation and economic growth. In particular, policy makers have embraced the view that debtor-friendly bankruptcy laws could enhance entrepreneurial activity and boost economic growth (see Audretsch, 2007; Ederer and Manso 2011). Instead, our results indicate that debtor protection could limit the growth of an important component of the entrepreneurial sector of the economy.

The paper is organized as follows. Section 2 details the institutional background of U.S. personal bankruptcy law. In Section 3 we review the related literature and develop our hypotheses. We present our empirical methodology in Section 4. The dataset and the variables used in our analysis are described in Section 5. Section 6 presents the results and Section 7 provides some robustness tests. Section 8 concludes. 


\section{Institutional setting}

\section{a. U.S. Personal Bankruptcy Law}

When an individual files for bankruptcy all collection efforts by creditors must terminate. There are two separate personal bankruptcy procedures in the U.S., Chapter 7 (a liquidation procedure) and Chapter 13 (a reorganization procedure). Under Chapter 7 filers keep all their future income but they must turn over any unsecured assets they own above the relevant state's exemption limits. ${ }^{4}$ The bankruptcy trustee uses these nonexempt assets to repay debt. As explained below, the exemption limits vary widely across states and time. Under Chapter 13 debtors can keep all of their assets, but they must propose to creditors a repayment plan. This plan typically involves using a portion of the debtor's future earnings over a five-year period to repay debt.

Before 2005 debtors were allowed to choose between Chapters 7 and 13 . Around 70 percent of all bankruptcy filings were made under Chapter 7 (White, 2007a). Debtors had an incentive to choose Chapter 7 over Chapter 13 whenever they had few nonexempt assets. In this way debtors maximized their financial benefit from filing for bankruptcy because they were able to preserve both their current assets and their future income. But this also means that the system permitted that most bankrupt individuals had no obligation to repay from future income, regardless of how high their incomes were.

The Bankruptcy Abuse Prevention and Consumer Protection Act (BAPCPA) of 2005 sought to prevent borrowers from abusing the bankruptcy regime. This legal

\footnotetext{
${ }^{4}$ Most unsecured debt, including credit card and personal loans are discharged in bankruptcy. In contrast, mortgages and other secured loans cannot be discharged. However, filing for bankruptcy often delays creditors from repossessing the collateral, because they must first obtain the bankruptcy trustee's permission to seize the assets. The probability of bankruptcy should thus reduce the value of both unsecured and secured claims.
} 
reform essentially introduced a means test that changed the bankruptcy options for individuals (but not for business owners, as we explain below). Under BAPCPA, only filers whose income over the previous six months is below the median for their state can file for Chapter 7 bankruptcy. Higher income debtors with sufficient means can file only for Chapter 13 bankruptcy. ${ }^{5}$ Otherwise, the provisions in Chapter 7 remain essentially unchanged. The state exemption limits remain in effect and Chapter 7 bankruptcy filers are obliged to turn over to creditors only their nonexempt assets.

As noted in White (2007b), the effects of BAPCPA on small business owners should be especially modest. The U.S. Bankruptcy Code explicitly prescribes that the means test applies to "consumer Chapter 7 cases." Entrepreneurs can file for Chapter 7 without being subject to the means test restriction as long as they have mainly business debts. White (2007b) also presents a variety of strategies that debtors can pursue in order to either bypass the means test or reduce their obligation to repay in the event that they do not qualify for Chapter 7. For instance, debtors at higher income levels can pass the means test by filing when their average income over the previous six months is low. In short, the 2005 reform should not change the way that exemptions affect indebted entrepreneurs, even if they have high asset and income levels.

\section{b. Bankruptcy exemptions}

Under Chapter 7 debtors are allowed to keep certain assets in bankruptcy up to the state's predefined exemption limits. A higher exemption level provides additional wealth insurance to debtors, as it reduces the asset value that creditors can seize in

\footnotetext{
${ }^{5}$ Another major change in the 2005 law is that debtors are no longer allowed to propose their own Chapter 13 repayment plan. BAPCPA implemented a procedure based on debtors' disposable income that determines how much they must repay. Other substantial changes of BAPCPA are that all filers must undergo six months of mandatory credit counseling, provide additional documentation, and pay higher filing fees.
} 
bankruptcy. Although the Bankruptcy Reform Act of 1978 established a uniform national set of exemptions, it allowed states to opt out and set their own exemption levels. About three quarters of the states opted out (Hynes, Malani, and Posner, 2004). As a result, exemption limits vary widely across states. ${ }^{6}$

There are several categories of asset exemptions. The most important is the homestead exemption, which provides protection for equity in the debtor's family residence. The homestead exemption varies from a few thousand dollars to unlimited. Lower exemption amounts are also available for various other types of personal property, such as clothing, furniture, cattle, guns, and motor vehicles. Many states offer wildcard exemptions that allow debtors to retain any personal property up to a specified dollar amount. The types of personal assets specified in the law vary considerably across states and many of these assets have unspecified exemption amounts. It is therefore infeasible to include all personal assets specified in these various state laws. Similar to Gropp et al. (1997), our measure of personal property exemptions includes only assets that have specific dollar amounts in most states: jewelry, motor vehicles, cash and deposits, and the wildcard exemption. In our empirical analysis we use a measure of state exemptions that combines the homestead exemption and the personal property exemptions.

\section{c. State laws amending bankruptcy exemptions}

From 2004 to 2011 many states enacted laws that increased their exemption levels. These laws can dictate an increase in the homestead exemption, in the personal property exemptions, or both. In most cases the same law amends the exemption

\footnotetext{
${ }^{6}$ Several states allow their residents to choose between the state and the federal exemptions. In these cases we selected the option that grants the claimant the highest exemption level. In some states, married couples are allowed to double the amount of the exemption when filing for bankruptcy together (called "doubling"). We have doubled all amounts except in those cases where bankruptcy law explicitly prohibits doubling.
} 
limits for various assets (e.g., homestead and motor vehicle). Table 1 lists the changes in exemptions that occurred during our sample period. ${ }^{7}$ The table shows that some states raised exemptions more than once (e.g., Idaho in 2006 and 2008). Furthermore, there is wide variation in the exemption amounts. The median change in exemptions is $\$ 21,200$. Some states made very small changes to their exemption limits (below $\$ 5000$ ), which typically reflect statutory increases in the nominal value of exemptions based on inflation. On the other end, ten states have very large increases in their exemption levels of $\$ 100,000$ or more.

\section{d. The political economy of exemption laws}

We are unaware of any study that investigates the political context behind these amendments in exemption limits that occurred in several states during 20042011. Anecdotal evidence we obtain from the legislative discussions preceding the laws that amended exemption limits highlights three supporting arguments: the increase in housing prices, the increase in medical costs, and the higher exemption levels offered by other states. ${ }^{8}$ In light of this evidence we cannot rule out that changing state economic conditions may have led to the passage of these laws. This raises obvious concerns regarding the identification of the effect of the exemptions. Our empirical strategy, which we explain in detail in Section 4, was designed to address these concerns.

\section{Related literature and hypotheses}

a. Exemptions and the supply of credit

\footnotetext{
7 In some cases there is a one-year gap between the law's approval date and when the law becomes effective. In this case we consider the year in which the law becomes effective.

${ }^{8}$ In the Internet Appendix we discuss these arguments in more detail.
} 
A higher exemption level makes borrowers more likely to file for personal bankruptcy and it reduces the amount of assets creditors can seize in bankruptcy. Moreover, it also increases the potential for opportunistic behavior by borrowers (Fay et al., 2002). Several papers find cross-sectional evidence consistent with banks reducing the supply of credit in response to the moral hazard problem. In particular, these papers find that in states with high exemptions banks are more likely to turn down loan applications from households (Gropp et al., 1997) and from SMEs (Berkowitz and White, 2004; Berger et al., 2011).

If a higher exemption level reduces entrepreneurs' ability to secure external financing, then it should also affect their real decisions. An important literature shows that financial constraints may force entrepreneurs to inefficiently reduce the scale of their ventures, hampering their performance and making them more vulnerable to failure (Evans and Jovanovic, 1989; Holtz-Eakin et al., 1994; Hurst and Lusardi, 2004; Kerr and Nanda, 2010). ${ }^{9}$ The credit supply channel should therefore have a negative effect on a firm's size and performance.

\section{b. Exemptions and wealth insurance}

Entrepreneurs face the risk associated with their firms' activities. A higher exemption level allows entrepreneurs to shelter more assets in bankruptcy, thereby decreasing their exposure to business risk. Gropp, Scholz, and White (1997) argue that the insurance provided by the exemption should lead risk-averse individuals to demand more credit. Kihlstrom and Laffont (1979) develop a general equilibrium model in which entrepreneurial decisions depend on the individual's level of risk aversion. They show that more risk-averse individuals become workers, while less

\footnotetext{
${ }^{9}$ Cerqueiro et al. (forthcoming) study the effect of exemptions on patenting by small firms. They find that an increase in exemptions reduces the number of patents produced by small firms, a result which is consistent with innovation being negatively affected by a reduction in credit availability.
} 
risk-averse individuals become entrepreneurs. Moreover, the less risk-averse entrepreneurs increase their exposure to business risk by hiring more employees and increasing the size of their ventures. A higher exemption level reduces the risk associated with entrepreneurship, and it could therefore: (i) make individuals more likely to become self-employed, and (ii) increase entrepreneurs' willingness to increase employment and expand their businesses. Consistent with the first prediction, Fan and White (2003), and Armour and Cumming (2008) document that debtorfriendly personal bankruptcy regimes have substantially higher self-employment rates. Our data do not allows us to study firm entry. Instead, we focus on the second prediction. We are not aware of any direct evidence linking debtor-protection to either firm employment or firm size.

In sum, the insurance mechanism predicts that following increases in exemptions, entrepreneurs should be more willing to obtain external financing and to expand the scale of their businesses by hiring more employees. Since the insurance mechanism goes in opposite direction to the credit supply channel, the effect of the exemptions on firm financing and performance is an empirical question.

\section{c. Exemptions and credit redistribution}

Which of the two above channels dominates could depend on the wealth level of the entrepreneur. Using the 1983 Survey of Consumer Finances, Gropp et al. (1997) document that the amount of debt held by high asset households is positively related to bankruptcy exemptions, while the amount of debt of low asset households is negatively related to the level of exemptions. In light of these findings they conclude that high exemptions redistribute credit from the less wealthy toward the more wealthy individuals. 
This redistribution effect finds theoretical support in Lilienfeld-Toal and Mookherjee (2016), who study the optimal design of personal bankruptcy law in a general equilibrium setting with contracts. A debtor-friendly regime reduces the amount of assets individuals can credibly pledge to creditors. However, this limited liability constraint is more binding for individuals with low wealth, who have few or no assets left to pledge, than for high wealth individuals, who still have pledgeable assets. As a result, their model predicts that a debtor-friendly regime redistributes credit from low wealth individuals to high wealth individuals.

This redistribution mechanism is important for two reasons. First, it alerts us to the fact that how the exemptions affect start-ups should depend on the entrepreneur's level of wealth. Second, it provides us with theoretical guidance to appropriately identify the effect of the exemptions. In light of the discussion above, the credit channel should dominate for low wealth entrepreneurs, and the insurance mechanism should dominate for the high wealth entrepreneurs.

\section{Empirical methodology}

We explain our identification strategy in two steps. Consider the following panel regression model:

$$
y_{i s t}=\alpha_{i}+\alpha_{t}+\beta \text { Exemp }_{s t}+\delta Z_{s t}+\gamma X_{i t}+u_{i s t}
$$

where $i$ indexes firms, $s$ indexes state, $t$ indexes time, $y_{i s t}$ is the dependent variable, $\alpha_{i}$ and $\alpha_{t}$ are firm and year fixed effects, Exemp $p_{s t}$ is the exemption amount in state $s$ at time $t, Z_{s t}$ are state control-level variables, $X_{i t}$ are firm-level control variables, and $u_{i s t}$ is an error term.

The year fixed effects control for aggregate shocks. The firm fixed effects control for all time-invariant heterogeneity at the firm and state level. Therefore, these 
fixed effects ensure that our identification of the exemptions effect comes entirely from changes in state exemption levels. In contrast to earlier literature (e.g., Gropp et al., 1997), we discard the vast cross-state variation in exemption levels and thus the possibility that differences in exemption levels might be picking other state-level characteristics. For instance, one might worry that states with high exemptions could attract less skilled (marginal) entrepreneurs who ex ante benefit more from the insurance provided by the exemptions. ${ }^{10}$ If these marginal entrepreneurs find it harder to obtain external financing and if their firms are more likely to underperform, then a cross-state analysis of the exemptions could yield biased estimates of their effects on firm financing and performance. In particular, one might conclude that high exemption levels reduce firm financing and cause them to underperform, while in reality that effect is driven by the lower quality of firms in high exemption states. The inclusion of firm fixed effects mitigates such concerns.

The coefficient $\beta$ measures the effect of the exemption laws. The following example illustrates how we identify this parameter. Rhode Island (RI) passed a law in 2006 raising the state's homestead exemption from $\$ 200,000$ to $\$ 300,000$. Suppose that we wish to analyze the effect of the law on bank financing. We could obtain such an estimate by simply subtracting the level of bank financing after 2006 from the one before 2006 for each firm located in RI. However, a contemporaneous change in credit market conditions in RI, for example, may have affected bank financing for all firms. To help control for changing economic conditions we could use a control state that did not raise exemptions in the same year, such as Connecticut (CT). If firms in CT were exposed to similar credit market conditions, their change in bank financing would measure the effect of such aggregate shocks. We can then compare the

\footnotetext{
${ }^{10}$ Fan and White (2003), and Armour and Cumming (2008) document that generous personal bankruptcy systems substantially increase the probability that an individual becomes self-employed.
} 
difference in bank financing obtained by firms in RI before and after 2006 with the same difference in CT. The difference of those two differences would therefore serve as an estimate of the effect of the increase in exemptions in RI.

Equation (1) has two additional virtues that are not readily visible in the above two-state example. First, the regression model accounts for the fact that we have several exemption laws staggered during our sample period. Consequently, our "control" group is not restricted to states that never raised exemptions. Equation (1) implicitly takes as the control group all firms located in states not changing exemptions at time $t$, even if they changed exemptions before or will change exemptions later on. Second, the regression model exploits variation in the dollar amounts by which exemption limits are amended. The model implicitly assumes that the effect of an exemption law increases proportionally with the size of the limit change. The variation in the intensity of the "treatment effect" provides better identification than the standard binary treatment outcome (i.e., whether a legal change occurred or not).

One important concern not addressed in Equation (1) is that local economic shocks could be correlated with the passage of the exemption laws. For instance, suppose that an adverse shock hit only RI at the same time it passed the exemption law. Our results would be biased toward finding a negative effect of the exemptions on firm financing, since the local economic shock would be correlated with both the exemption law and local banking market conditions. To control for such changing economic conditions we exploit differential effects of the exemptions on three types of entrepreneurs (Low wealth, Mid wealth, and High wealth). ${ }^{11}$ The baseline regression model we estimate is:

\footnotetext{
${ }^{11}$ Section 5 describes the wealth groups in detail.
} 


$$
\begin{aligned}
y_{i s t}= & \alpha_{i}+\lambda_{t}+\beta \text { Exemp }_{\text {st }}+\beta^{\text {Low }} \text { Exemp }_{s t} \times \text { LowWealth }_{i}+ \\
& +\beta^{\text {High }} \text { Exemp }_{\text {st }} \times \text { HighWealth }_{i}+\delta Z_{s t}+\gamma X_{i t}+u_{i s t} .
\end{aligned}
$$

The other variables are defined as in Equation (1). There are three coefficients of interest. The coefficient $\beta$ measures the effect of the exemptions for the Mid wealth entrepreneurs (the omitted category), while $\beta^{\text {Low }}$ and $\beta^{\text {High }}$ measure the differential effects relative to the omitted category for the Low wealth and High wealth entrepreneurs, respectively. The differential effects are crucial in our identification strategy for two reasons. First, they filter out the effects of local economic shocks affecting all firms in the state passing the exemption law. Second, these differential effects allow us to identify the effect of the exemptions in accordance with theory (Lilienfield-Toal and Mookherjee, 2016).

In addition to the baseline regression in (2), we also estimate two alternative specifications. The first adds interactions of the year dummies with the wealth groups in order to control for any aggregate shocks affecting entrepreneurs with different levels of wealth. The second adds interactions of the year dummies with state fixed effects in order to control for any state-level shocks. In this specification we can only identify the differential effects of the exemptions relative to the Mid wealth group.

When analyzing firm exit, we estimate a multiperiod logit regression in which the dependent variable equals zero if the firm is alive in year $t$, and equals one if the firm stopped its operations in year $t .^{12}$ This multiperiod logit regression is similar to Equation (2) except that we are forced to drop the firm fixed effects due to the incidental parameter problem. In exchange, we control for differences across firms and entrepreneurs with industry dummies and with several characteristics of the

\footnotetext{
${ }^{12}$ The multiperiod logit models in our firm exit regressions are equivalent to discrete-time hazard models (Shumway, 2001).
} 
entrepreneur, such as education and experience (see Table 3 for the complete list of variables). In addition, we add state fixed effects in our survival regressions to ensure that identification of the exemptions comes only from changes in state exemptions.

\section{Data and variables}

This paper uses confidential data from the Kauffman Firm Survey (KFS). The KFS is a longitudinal survey that collected information for a sample of 4,928 start-ups that began operations in 2004 in the United States and that are followed annually until 2011. We use the entire KFS panel, which comprises eight years of data (2004-2011). The KFS contains detailed information on the financial injections these firms received in each year. The survey also provides detailed information on the firm, such as its credit history, geographic location, industry, and information on the owners, such as experience, education, gender, race, age, and, starting in 2008, net worth. The KFS uses weights that make it representative of the 2004 population of start-ups in the U.S., and all of our analyses use these weights. ${ }^{13}$

We build our panel data as follows. We start with the full sample of firms surveyed in 2004 and append all subsequent survey waves. Each year there is some loss in sample size because some firm owners cannot be located, refuse to respond to the follow-up survey wave, or cease operations. When a firm exits the KFS, we assign a zero to all variables in that year and remove the firm from the sample after that.

Table 2 provides definitions of variables and summary statistics for the initial sample of start-ups in 2004. Below, we describe separately the variables in each group.

\section{a. Bank financing}

\footnotetext{
${ }^{13}$ The KFS data oversampled high-tech firms. The KFS weights were designed to make the sample representative of the frame from which the sample was drawn. See DesRoches et al. (2011) for additional details on the KFS sample design.
} 
Robb and Robinson (2014) document that outside debt - most of which is obtained from banks - is the largest single financing category for the KFS start-ups. The KFS enables us to separate credit obtained in the name of the firm's owner that is used to finance the firm's operations (Personal credit) from credit obtained in the name of the firm (Business credit). We note that all financing variables are measured as annual flows. The KFS also provides detailed information about different modes of personal bank financing, including credit cards and other bank loans. We observe both the lending balance and the credit limit of the credit cards that the entrepreneur claims to use to finance the firm's operations. ${ }^{14}$ Other personal loans measures the amount of personal credit obtained, excluding credit card financing.

\section{b. Employment}

We use two measures of firm employment. First is the number of full-time employees including the firm owner. About half of the firms in our sample report that they have no employees. Therefore, we also create the dummy variable Firm is employer that indicates whether or not the firm has employees in the specific year.

\section{c. Revenue and efficiency}

Generates revenue is a dummy that indicates whether the firm generates revenue. We also use a firm's revenue to create a measure of the firm's operating efficiency, Efficiency, which we define as the average revenue generated by each employee (including the firm owner).

\section{d. State variables}

\footnotetext{
${ }^{14}$ Robb and Robinson (2014) and Chatterji and Seamans (2012) document the importance of credit card financing for nascent firms. Brown, Coates, and Severino (2014) find that higher bankruptcy exemptions increase the level of credit card debt held by households.
} 
Our main variable of interest is Exemptions, which equals the sum of the homestead exemption and the personal property exemption in the state. ${ }^{15}$ We obtain the exemption values from individual state legal codes. Table 1 provides all exemption changes occurred between 2005 and $2011 .{ }^{16}$ We use the House Price Index from the Federal Housing Finance Agency to control for changing conditions in real estate markets. In order to control for changes in other economic conditions, we add the state median household income and the rate of unemployment, which we obtain respectively from the Census Bureau and from the Bureau of Labor Statistics.

\section{e. Firm characteristics}

The KFS contains the commercial credit score class of the firm from Dun \& Bradstreet, which ranges from 1 (minimum risk) to 5 (maximum risk). The credit scores are not available for about one fourth of our sample, as Dun \& Bradstreet sometimes did not have enough information to produce a score. We decompose the credit score variable into a set of six mutually exclusive dummy variables, with the "missing credit score dummy" as the omitted category. We also create an indicator of whether the firm adopted a limited liability form.

\section{f. Owner characteristics}

We use several demographic characteristics of the firm owner when studying firm failure. The first characteristic is experience, which we measure as the number of years worked in the industry, the number of businesses started by the firm owner, and an indicator of whether the owner started other businesses in the same industry. Second, we create the dummy Minority that indicates whether the owner is non-white.

\footnotetext{
${ }^{15}$ For details on the different types of exemptions, see subsection 2.b.

${ }^{16}$ There are no reductions in exemption limits during our sample period. In the descriptive statistics we assign a value of $\$ 1$ million to the states with unlimited homestead exemptions. This assumption is irrelevant for our empirical analysis because no state changed its homestead exemption level from or to unlimited during our sample period.
} 
Third, we control for education with the variables High school and College degree, which indicate the level of highest education attained.

\section{g. Owner wealth}

The KFS introduced a question about the primary owner's personal net worth only in its fourth follow-up survey (in 2008). The 2008 KFS reports entrepreneur wealth divided into five intervals: (i) $\$ 0$ or less, (ii) $\$ 1$ to $\$ 50,000$, (iii) $\$ 50,001$ to $\$ 100,000$, (iv) $\$ 100,001$ to $\$ 250,000$, and (v) $\$ 250,001$ and up. Because some of these intervals have relatively few observations, we aggregate them into three wealth groups: Low wealth (includes entrepreneurs with wealth up to $\$ 50,000$ ), Mid wealth (includes entrepreneurs with wealth between $\$ 50,001$ and $\$ 250,000$ ), and High wealth (includes entrepreneurs with wealth above $\$ 250,000$ ). Since several firms went out of business between 2004 and 2008, information about net worth is available for only about $53 \%$ of the initial sample. The missing information about wealth in the early waves of the KFS poses a non-trivial problem. On the one hand, using data starting in 2008 is infeasible because it greatly reduces the number of sampled firms and raises sample selection concerns. On the other hand, using a measure of wealth reported as of 2008 to analyze firm financing and performance for the entire KFS panel could raise the concern that reported wealth could itself be partly determined by those outcomes.

To overcome these limitations, we estimate a predictive model of the entrepreneur's wealth group based on several firm and owner characteristics. The predictive model allows us to obtain wealth estimates for all firms in the sample (as long as information on the predictors is not missing), thus addressing the missing data problem. In addition, the model predicts an entrepreneur's wealth group using only pre-determined variables (measured as of 2004 or before), which makes our wealth 
group measure fairly exogenous with respect to subsequent firm outcomes. We use three types of variables to estimate the wealth groups: (i) firm level characteristics (legal form and industry), (ii) zip-code level characteristics from the 2000 Census (proportion of whites, average house value, and average income per household), and (iii) characteristics of the entrepreneur (experience, education, age, gender, and race). In the Internet Appendix we describe in detail the predictive model and the variables used.

Based on this procedure, we construct three time-invariant wealth variables that measure the probability that an entrepreneur belongs to the Low wealth, Mid wealth, or High wealth group. Low wealth indicates that the net worth of the main firm owner is lower than $\$ 50,000$. Mid wealth indicates that the net worth of the main firm owner is between $\$ 50,000$ and $\$ 250,000$. High wealth indicates net worth greater than $\$ 250,000$. In our regressions we use these predicted probabilities (interacted with the exemptions variable) as an "instrument" for the entrepreneur's wealth group. ${ }^{17}$

Table 3 displays summary statistics by wealth group for the initial survey wave. In the Internet Appendix we explain how we assign entrepreneurs to each wealth group in a binary rather than in a probabilistic way. The wealth groups we obtain with our probabilistic model seem very reasonable in terms of their observable characteristics. For example, on average wealthier entrepreneurs found larger companies (they obtain higher initial financing amounts and hire more employees). In addition, wealthier entrepreneurs are more likely to incorporate their companies, and are more educated, while low wealth entrepreneurs are more likely to belong to minority groups.

\footnotetext{
${ }^{17}$ In the Internet Appendix (Section F) we compare the results of predicted wealth versus reported wealth for the overlap sample and show that our main conclusions hold when we use the reported wealth group.
} 


\section{Results}

\section{a. Bank financing: Personal credit and Business credit}

We first study the effect of changes in state exemptions on start-ups' bank financing. The KFS distinguishes between bank loans used for business purposes that are obtained in the name of the firm owner (Personal credit) and those in the name of the business (Business credit). This distinction is important because personal bankruptcy law applies directly only to personal liabilities of the entrepreneur. ${ }^{18}$ Therefore, analyzing the effect of the exemptions on business credit serves as a good counterfactual and allows to rule out alternative explanations for our findings. For example, if exemptions are correlated with state-wide economic shocks, we would expect similar effects on personal loans as on business loans. However, if our identification strategy is correct, business loans should not be affected by the increase in exemptions or, if affected, they should move in the opposite direction, as firms may substitute one source of funding for the other.

In Table 4 we report how changes in exemptions affect the inflows of personal credit and business credit (both measured in logs). We estimate the effect of the exemptions for three wealth groups. The variable Exemptions measures the effect of the exemptions for Mid wealth entrepreneurs (the omitted wealth category). Interactions of this variable with Low wealth and High wealth measure the differential impact of the exemptions between the Mid wealth and each of the two other groups. These differential effects should filter out any economic shocks affecting all entrepreneurs in the state passing the exemption law. The exemptions are expressed in millions of dollars and thus the coefficients associated with this variable can be

\footnotetext{
${ }^{18}$ In firms with unlimited liability form all credits are de facto personal since there is no legal distinction between the firm and the owner. Consequently, the distinction between personal credit and business credit is meaningful only for limited liability firms. In our sample $44 \%$ of the owners of limited liability firms report that they borrow at the personal level to finance the firm's operations.
} 
interpreted approximately as the percent change in the dependent variable that results from raising exemptions by $\$ 10,000$.

We report three specifications for each dependent variable. The first specification includes firm fixed effects and year dummies. The second specification adds interactions of the year dummies with the wealth groups. The third specification adds instead interactions of the year dummies with state fixed effects, which controls for any state-level shocks. In this specification we can only identify the differential effects of the exemptions relative to the Mid wealth group. All specifications include a full set of credit score dummies (the omitted category is a missing credit score) and several state controls (changes in the house price index, median income, and unemployment rate). Standard errors are clustered at the state level.

Columns 1 and 2 of Table 4 show that the exemptions reduce personal credit for the Mid wealth entrepreneurs. The estimated effects are statistically significant and economically meaningful. They indicate that these entrepreneurs permanently reduce the inflow of personal credit by $6 \%$ for a $\$ 10,000$ increase in the exemption limit. ${ }^{19}$ The drop in personal credit implies that the supply channel dominates a potential increase in the demand for credit, for entrepreneurs with intermediate levels of wealth.

We obtain positive differential effects for the Low wealth and High wealth groups, which more than offset the negative coefficient obtained for the Mid wealth group. Column 3 shows that these differential effects hold even when we control for state-level shocks. Our results thus indicate that the exemptions have no absolute effect on the inflow of personal credit for both the lowest and highest wealth groups. ${ }^{20}$

\footnotetext{
${ }^{19}$ Recall that out measure of wealth is a probabilistic one (see Section 5 and the Internet Appendix for details). To facilitate interpretation of the wealth variables, we scaled the wealth probabilities of each individual by the sample means of the corresponding wealth groups. Therefore the coefficient on Exemptions measures precisely the effect of the exemptions for an average Mid wealth entrepreneur.

${ }^{20}$ The coefficient on the variable Exemptions measures the absolute effect of the exemptions for the Mid wealth group. To calculate the absolute effects for the other two wealth groups, we sum this
} 
These findings indicate that the increase in exemptions reduces significantly the debt capacity of Mid wealth entrepreneurs relative to the two other wealth groups. Entrepreneurs with intermediate levels of wealth experience the sharpest decline in pledgeable assets when the exemptions increase, since most or all of their wealth become protected under the new exemption limit. Put differently, the exemptions impose a tighter limited liability constraint on these entrepreneurs that reduces their access to credit. In contrast, High wealth entrepreneurs still have plenty of unprotected assets remaining and thus face a weaker limited liability constraint. Low wealth entrepreneurs should also be less affected by the increase in exemptions, since they had nothing to protect even under the previous exemption level.

Our estimates actually point to a modest, albeit insignificant, absolute increase in personal credit for the Low wealth and the High wealth groups. From a general equilibrium perspective, these entrepreneurs could benefit from an increase in exemptions, since lenders may redistribute credit away from individuals who experience the sharpest fall in pledgeable wealth towards other individuals (Lilienfeld-Toal and Mookherjee, 2016).

In Columns 4 and 5 of Table 4 we see no significant effect of the exemptions on the inflow of business credit for the Mid wealth group. This is an important result. Business credit is a good counterfactual, because, while it should not be affected directly by personal bankruptcy law, it could still be susceptible to any economic shocks affecting the company. For instance, if the companies owned by Mid wealth individuals were hit by some state-wide negative shock contemporaneous with the exemptions, then this shock would likely reduce all types of bank financing. The fact Low wealth group is the sum of the coefficients Exemptions and Exemptions XLowWealth. 
that we obtain a significant effect of the exemptions only for personal credit strongly suggests that our estimates are indeed picking up the effects of the exemption laws.

The differential effects we obtain for business credit are also insignificant in most cases. One exception is the specification in Column 6 that includes StatexYear fixed effects, which produces a positive and significant differential effect of the exemptions for the Low wealth group. As shown in the robustness section, this effect disappears when we allow the three wealth groups to be on different trends.

With respect to control variables, firms that improve their credit scores obtain substantially larger inflows of both types of bank financing. ${ }^{21}$ The estimated coefficients for the credit score dummies increase monotonically as we move toward the highest scores, and most coefficients are statistically significant. The insignificant coefficients we obtain for the lowest rating (Credit risk 5) indicates that these high risk companies obtain about the same level of financing as a company that does not have a credit score.

\section{b. Personal credit: Credit cards and Other bank loans}

The level of detail of the KFS allows us to further analyze the two main types of personal bank loans used to finance the firm: credit card financing and other personal loans. For the credit cards we observe both the amount used and the credit limit. Credit card financing is interesting for us for several reasons. First, it is a popular source of start-up financing (Chatterji and Seamans, 2012; Robb and Robinson, 2014). Second, credit cards are important liquidity providers that entrepreneurs can tap to face temporary shocks. Third, personal bankruptcy law applies directly to unsecured lending, such as credit cards. Evidence from the

\footnotetext{
${ }^{21}$ The credit scores contain information not only about the business, but also about the firm owners, such as past delinquencies. The inclusion of personal information explains why the credit scores matter also for personal credit.
} 
consumer credit market point to an increase in credit card debt following an increase in exemptions (Brown et al, 2014).

In Table 5 we show the effect of the exemptions on the credit card balance (Columns 1-3), credit card limit (Columns 4-6), and the inflow of other personal bank loans (Column 7-9). All three dependent variables are in logs. The exemption limits are expressed in millions of dollars. We report three specifications for each dependent variable. The first specification includes firm fixed effects and year dummies. The second specification adds interactions of the year dummies with the wealth groups, and the third specification adds instead interactions of the year dummies with state fixed effects. All specifications include a full set of credit score dummies (the omitted category is a missing credit score) and several state controls (changes in the house price index, median income, and unemployment rate). Standard errors are clustered at the state level.

The evidence in Table 5 points to an insignificant decline in credit card debt for the Mid wealth entrepreneurs (Columns 1 and 2). However, we obtain a positive and significant differential effect for High wealth entrepreneurs that holds when we include StatexYear fixed effects in Column 3. This differential effect is economically important. The estimated coefficient indicates that a $\$ 10,000$ increase in the exemption limit increases credit card debt by $4 \%$ relative to Mid wealth entrepreneurs.

Columns 4-6 show that the economic effects we obtain for credit card debt are amplified for the credit card limit, which is a better proxy for credit supply. In Columns 4 and 5 we find that Mid wealth entrepreneurs face a reduction in their credit card limits of around 5\% following a $\$ 10,000$ increase in exemptions. This is consistent with our earlier finding that the exemptions reduce the supply of personal credit to Mid wealth entrepreneurs. 
Low wealth entrepreneurs seem not to be affected by the exemption increase. Although the estimated differential effects are not statistically significant, they offset the negative effect found for the intermediate wealth group. In contrast, the differential effect for the High wealth group remains significant and becomes much stronger across all three specifications. Our estimates indicate that these wealthier entrepreneurs actually increase their credit card limit by $4 \%$ in absolute terms following a $\$ 10,000$ increase in the exemption limit (relative to the intermediate wealth group, the increase is $10 \%$ ). This result provides additional evidence that bankruptcy exemptions redistribute credit toward the wealthiest entrepreneurs (Gropp et al., 1997; Lilienfeld-Toal and Mookherjee, 2016). This result is also consistent with the evidence in Severino et al. (2014). They find a strong effect of the exemptions on consumer credit card in areas with high home ownership rates, which are presumably populated by wealthier individuals.

In Columns 7 and 8 we show that the exemptions also appear to reduce the inflow of other personal bank loans only to Mid wealth entrepreneurs, although the effect is only marginally significant in the first specification. The differential effects obtained are only significant for the Low wealth group, indicating that these entrepreneurs experience a relative increase in other types of loans (includes loans from banks or from other financial institutions). Our estimates indicate that the inflow of other personal loans to Low wealth entrepreneurs increases in absolute terms by $2 \%$ following a $\$ 10,000$ increase in exemptions. This effect is statistically significant at the $5 \%$ level in Column 7 and at the $10 \%$ level in Column 8.

In sum, the effect of personal bankruptcy on the financing opportunities of entrepreneurs depends crucially on how severely the limited liability constraint binds. Entrepreneurs whose wealth becomes mostly or entirely protected by the higher 
exemption limit suffer a steep reduction in personal credit. In contrast, the wealthiest entrepreneurs, who retain large amounts of assets to pledge, are able to maintain - if not increase - their level of personal borrowing following an increase in exemptions. The least wealthy entrepreneurs also appear to benefit from higher credit availability. While the change in exemptions does not affect the pledgeable wealth of Low wealth individuals, the higher exemption level puts these entrepreneurs on equal standing with the Mid wealth entrepreneurs and enables them to compete for the same scarce resource (credit).

We next investigate whether the changes in credit availability triggered by the change in exemptions affect firm employment, revenue, and performance.

\section{c. Firm employment}

A reduction in credit availability can prevent entrepreneurs from expanding their ventures and even force them to operate at a smaller scale. Our earlier financing results show that this negative credit channel affects only Mid wealth entrepreneurs. At the same time, the exemptions seem to redistribute credit towards the two other wealth groups. An increase in credit availability could encourage these entrepreneurs to expand their businesses and to hire employees, especially for entrepreneurs who were particularly credit constrained before.

In order to assess the effects of the exemptions on employment, we use two measures. The first is the logarithm of the number of firm employees (including the firm owner). Since several start-ups in our sample report zero employees, we use as a second measure a dummy that indicates whether the firm has any external employees. Our findings are reported in Table 6. The exemption limits are expressed in millions of dollars. As before, the first specification includes firm fixed effects and year dummies, the second specification adds interactions of the year dummies with the 
wealth groups, and the third specification adds instead interactions of the year dummies with state fixed effects. All regressions include credit score dummies (the omitted category is a missing credit score) and several state controls (changes in the house price index, median income, and unemployment rate). Standard errors are clustered at the state level.

Columns 1-3 of Table 6 show that an increase in exemptions has little effect on employment levels. Although Mid wealth entrepreneurs seem to reduce employment (Columns 1 and 2), the estimated effects are statistically insignificant. The differential effects obtained for the other wealth groups are positive, but only marginally significant for the Low wealth entrepreneurs in Column 1.

In Columns 4-6 we report coefficient estimates from linear probability models of a firm's decision to have employees. We find that an $\$ 10,000$ increase in the exemption limit reduces the likelihood that a Mid wealth entrepreneur has employees by around 0.5 percentage points. ${ }^{22} \mathrm{We}$ interpret this result as evidence that tighter credit constraints force these Mid wealth entrepreneurs to scale down operations. For the two other wealth groups we obtain positive and significant differential effects of the exemptions. There is, however, one important difference between them. While in absolute terms the likelihood of hiring remains virtually unchanged for the wealthiest entrepreneurs, it increases significantly for the least wealthy entrepreneurs. In particular, we find that Low wealth entrepreneurs are 0.4 to 0.48 percentage points more likely to have employees following a $\$ 10,000$ increase in the exemption limit (both effects are significant at the 5\% level).

\footnotetext{
${ }^{22}$ In 2004 the fraction of firms owned by Mid wealth entrepreneurs with external employees was $40 \%$. If one takes the median change in exemptions $(\$ 21,400)$, the estimated drop in the likelihood of employment by these firms is $2.7 \%$.
} 
The increase in employment by Low wealth entrepreneurs is consistent with our earlier finding that these individuals have greater access to personal loans, which enables them to scale up their operations. ${ }^{23}$ The fact that we find no increase in employment for the High wealth entrepreneurs suggests that these wealthier individuals were unconstrained and already operating at their desired scale.

\section{d. Firm performance}

Bankruptcy exemptions affect start-ups' financing opportunities and employment decisions. In Table 7 we investigate how the exemptions affect a firm's ability to generate revenue and its operating efficiency. We measure firm efficiency as the log of revenue per employee. As before, the exemption limits are expressed in millions of dollars. The first specification includes firm fixed effects and year dummies, the second specification adds interactions of the year dummies with the wealth groups, and the third specification adds instead interactions of the year dummies with state fixed effects. All regressions include credit score dummies (the omitted category is a missing credit score) and several state controls (changes in the house price index, median income, and unemployment rate). Standard errors are clustered at the state level.

Columns 1 and 2 show that firms owned by Mid wealth entrepreneurs are less likely to generate revenue following an increase exemptions. This result is not surprising, given our earlier finding that these firms are less likely to have employees. However, Columns 4 and 5 further show that the revenue per employee also falls, which we interpret as a decline in operating efficiency of firms operated by Mid

\footnotetext{
${ }^{23}$ The increase in exemptions is similar to an increase in wealth insurance. As a response, entrepreneurs may become less risk averse and increase their demand for credit and their willingness to expand their business by hiring employees. This insurance mechanism could also affect entrepreneurs without unprotected wealth (i.e., the Low wealth) to the extent that they are forward-looking, and perceive that such insurance protects their future wealth.
} 
wealth entrepreneurs. The estimated coefficients indicate that revenue per employee falls on average by $3.2 \%$ to $4 \%$ for a $\$ 10,000$ increase in the exemption limit. We interpret these findings as evidence that credit constraints force these firms to downsize to a below-optimal scale (Evans and Jovanovic, 1989).

In line with our employment results, we find that firms owned by Low wealth entrepreneurs are more likely to generate revenue and become more efficient following an increase in exemptions. Not only are the estimated differential effects significant for this group, but the absolute effects are also significant at the $1 \%$ level. For example, the results in Column 2 show that these firms are 0.55 percentage points more likely to generate revenue after a $\$ 10,000$ increase in exemptions. ${ }^{24}$ In turn, the coefficient estimates in Column 5 point to an absolute increase in revenue per employee of $2.6 \%$ following a $\$ 10,000$ increase in exemptions.

For the High wealth entrepreneurs we find no significant effects of the exemptions on revenue and efficiency.

Finally, we investigate whether the exemptions affect firm survival. An inefficient small firm that does not generate adequate revenue should be more prone to failure. In light of previous results, firms owned by Mid wealth entrepreneurs should be most negatively affected. This is precisely what we find in Table 8 . We estimate a multiperiod logit model to test whether the passage of the exemption laws affects the probability of firm exit. The exemption limits are expressed in millions of dollars. Because we cannot have firm fixed effects, we include instead state fixed effects and add several firm and owner characteristics to control for time-invariant heterogeneity. ${ }^{25}$ As in the previous models, we also include state controls (changes in

\footnotetext{
${ }^{24}$ The fraction of firms owned by Low wealth entrepreneurs that generated revenue in 2004 was $58 \%$. If one takes the median change in exemptions $(\$ 21,400)$, the estimated effect is that these firms are $2 \%$ more likely to generate revenue.

${ }^{25}$ See Table 2 for the complete list of variables.
} 
the house price index, median income, and unemployment rate), and credit score dummies. Standard errors are clustered at the state level.

The results In Table 8 show that firms owned by Mid wealth entrepreneurs become more likely to fail following an increase in the exemptions. The estimated coefficient indicates that a $\$ 10,000$ increase in the exemption limit raises the likelihood of failure by almost three percentage points. This result corroborates our previous findings of a negative effect of exemptions on employment, revenue, and efficiency for these entrepreneurs. Survival chances of firms owned by the other types of entrepreneurs are not affected in absolute terms.

We note that the negative real effects we find for Mid wealth entrepreneurs are unlikely due to adverse economic shocks hitting states that raised their exemption limits. As explained before, such economic shocks should also affect the other entrepreneurs located in the same state. We do not find such evidence. Instead, our results suggest that the reduction in credit supply triggered by the change in exemptions forces affected start-ups to operate at a smaller scale and makes them more likely to fail.

\section{Robustness tests}

\section{a. Pledgeable wealth and firm financing}

Because the level of exemptions varies widely across states and because the changes in exemptions are very diverse in terms of magnitude, individuals in the intermediate wealth group should not always be the most affected by a change in exemptions. In order to get a more precise assignment of individuals to the treatment group, we redefine our wealth groups comparing the wealth of the entrepreneurs with the exemption levels.

Specifically, we first estimate the wealth of each entrepreneur using the mid 
points of the wealth bins and the probabilities we estimated to build our wealth proxy (recall that we do not observe their actual wealth, but only the wealth bin in which each entrepreneur falls; see the Internet Appendix for details on how we estimate the wealth probabilities). For instance, suppose our estimated probabilities for an entrepreneur were the following: $\operatorname{Prob}($ Low wealth $)=0.7, \operatorname{Prob}($ Mid wealth $)=0.25$, and $\operatorname{Prob}($ High wealth $)=0.05$. Given that the mid points of the respective wealth bins are $\$ 25,000, \$ 150,000$, and $\$ 500,000$, the estimated wealth for this entrepreneur is $0.7 * \$ 25,000+0.25 * \$ 150,000+0.05 * \$ 500,000=\$ 80,000$.

Second, we compare the entrepreneur's estimated wealth with the exemption level in her state of residence. In particular, we redefine our wealth groups as follows. The first group contains entrepreneurs whose estimate of wealth is below the state exemption limit in all years. Since these entrepreneurs are fully protected during our sample period, they correspond conceptually to our Low wealth group.

The second group contains entrepreneurs whose estimate of wealth is above the state exemption limit in all years. Since these entrepreneurs maintain some pledgeable wealth during our sample period, they correspond to our High wealth group. The third group therefore contains entrepreneurs who run out of pledgeable wealth during our sample period, corresponding to our Mid wealth group.

Third, we re-estimate the regressions in our paper in order to assess the differential effect of the exemptions across these redefined wealth groups. We report the results in Table 9. Since the specifications shown contain state*year fixed effects, we are only able to identify the interaction of the exemptions with indicators for the redefined Low wealth and High wealth groups (which for simplicity we label LowWealthAdj and HighWealthAdj). The findings we obtain with this approach are very consistent with those we report in the paper (Table 4 and 5). When exemptions 
increase, individuals with high wealth get more personal loans and higher credit card limits relative to the individuals who run out of pledgeable wealth during our sample period. Importantly, we find no such effect for business loans.

\section{b. Parallel trends}

We start by testing for each wealth group whether there are significant differences in pre-trends between treated states and control states. The results are in reported in the Internet Appendix (tables $\mathrm{C} 1$ to $\mathrm{C} 4$ ). For each dependent variable, the first column replicates the results reported in the second specification of our main tables. The second column reestimates the regressions allowing for differential pretrends. The variable Pre-trend is a linear time trend that stops when a first change in exemptions occurs, after which point it takes the value of zero. Treated is a dummy variable that indicates whether the state passed an exemption law during our sample period. For the financing variables (Tables $\mathrm{C} 1$ and $\mathrm{C} 2$ ), we find insignificant differences in pre-trends for all wealth groups. For the real variables (Tables C3 and C4), we find evidence of negative differential pre-trends for the Low wealth entrepreneurs (for revenue and efficiency) and for the High wealth entrepreneurs (for employment). We note, however, that the misaligned trends actually go against our results and cannot explain the negative effects we find for the Mid wealth group.

In the third column of the same tables, we reestimate the same regressions explicitly allowing for differential trends. Trend is a linear time trend. Although the differential trends often absorb part of the effect of interest, we find that many of our results remain statistically significant when we explicitly control for differential trends. These results thus corroborate our identification strategy.

\section{c. Standard errors}


In our regressions we clustered standard errors at the state level. The fact that our wealth measures are generated regressors could raise the concern that the estimated standard errors are too small, leading to over confidence in our results. The survey design of the KFS limits the possibilities for calculating standard errors. For instance, the fact that we employ survey weights in estimation does not allow us to bootstrap standard errors. For this reason, we obtain standard errors using jackknife as an alternative resampling method. This non-parametric technique essentially uses subsets of available data without replacement to build the empirical distribution of the point estimate. ${ }^{26}$ The results reported in the Internet Appendix (tables D1 to D5) show that our main findings remain statistically significant.

\section{d. The role of firm age}

In this subsection we examine how exemptions affect firms differently depending on their age. Firms may be more likely to borrow when young due to cashflow constraints, exacerbating the limited liability constraint introduced by the increase in exemptions. Since all firms in our sample started in 2004, the variation we have in firm age is collinear with time. Keeping in mind this limitation of our panel dataset, we present some results in the Internet Appendix (table E1) that are suggestive of firms being more credit constrained when they are young. In this Table, we replicate the regressions of Table 4 replacing the Exemptions variable with two interaction terms: Exemptions* ${ }^{*}$ Age $\left.<4\right)$ and Exemptions* ${ }^{*}($ Age $\geq 4)$. The first term measures the effect of a change in exemptions on firms when they are younger (less than 4 years old), while the second term measures the same effect for older firms (when the firm is 4 or more years).

\footnotetext{
${ }^{26}$ The procedure we use is "delete-1 Jackknife", in which samples are selected by taking the original data and deleting one firm from the set.
} 
As before, the results support our empirical strategy as we only find significant effects for personal financing (Column 1), with no effects for business financing (Column 2). In particular, we find that that the negative effect of the exemptions on the Mid wealth group is slightly stronger when firms are young, which is consistent with the prior that younger firms are more likely to have cash flow constraints. Moreover, the redistribution of credit towards Low wealth entrepreneurs also appears to be stronger for younger firms, suggesting that these firms were previously more credit constrained than older firms. Finally, the positive effect we find for the High wealth entrepreneurs seems independent of age.

\section{e. Other robustness tests}

Finally, we analyze how right-censoring affects our results. We report in Table G1 in the Internet Appendix results for our main table in the paper, in which we analyze the effect of the exemptions on Personal credit and Business credit. In columns 1 and 5 we replicate the results in the paper that use the entire sample. In columns 2 and 6, we remove observations for states that increased exemptions in 2011 (but keep those states in the sample before they increase exemptions). In columns 3 and 7, we remove observations for states that increased exemptions in 2010 and 2011. And in columns 4 and 8 we remove observations for states that increased exemptions in 2009, 2010, and 2011. The evidence in the Internet Appendix show that our results are not driven by exemption changes towards the end of our period.

\section{Conclusion}

Recent evidence highlights that start-ups are important job creators in the U.S. In this paper we show that recent state changes to personal bankruptcy exemption limits have important effects on the availability of credit, employment, and performance of local start-ups. When a state raises the amount of personal wealth that 
is protected in bankruptcy, entrepreneurs whose wealth becomes fully protected suffer a strong reduction in credit availability. For entrepreneurs who either were already protected before (the least wealthy entrepreneurs) or still have unprotected assets under the new exemption limit (the wealthiest entrepreneurs), we find a modest increase in credit availability. Our results indicate that more debtor-friendly bankruptcy regimes redistribute credit, as predicted in Lilienfeld-Toal and Mookherjee (2016).

We also find strong evidence that these credit market frictions triggered by changes in exemptions actually affect young firms' real outcomes. In particular, the reduction in credit availability makes affected entrepreneurs less likely to hire employees, reduces revenues and operating efficiency, and makes their firms more likely to fail. In contrast, start-ups owned by the least wealthy entrepreneurs become more likely to hire employees and experience a significant improvement in operating efficiency. These real effects results are thus consistent with the alleviation of credit constraints for the least wealthy entrepreneurs. For the wealthiest entrepreneurs, we find no significant effects on firm performance.

Our results have important policy implications. A higher level of debtor protection reduces entrepreneurs' asset pledgeability. We show that this limited liability constraint reduces credit availability to these entrepreneurs, forcing them to operate their firms at a smaller scale, and making them more vulnerable to failure. Therefore, our results confirm that access to capital is an important determinant of start-up growth and survival (Evans and Jovanovic, 1989; Holtz-Eakin et al., 1994).

This paper focuses on the effects of the exemptions on start-ups along the intensive margin. One question that we cannot address due to the nature of our data is how the exemptions affect firm entry. An increase in exemptions presumably makes 
entrepreneurship more attractive for risk-averse individuals, since they obtain additional wealth insurance in case they fail. At the same time, it can also increase failure rates of new entrants if these new firms cannot access credit. While we find this question promising, we leave it for future research. 


\section{References}

Adelino, M., Ma, S., \& Robinson, D. (2014). Firm Age, Investment Opportunities, and Job Creation. Working paper.

Albuquerque, R. \& Hopenhayn, H. (2004). Optimal Lending Contracts and Firm Dynamics. Review of Economic Studies 71(2), 285-315.

Armour, J. \& Cumming, D. (2008). Bankruptcy law and entrepreneurship. American Law and Economics Review, 10, 303-350.

Berger, A. N., Cerqueiro, G., \& Penas, M. F. (2011). Does debtor protection really protect debtors? Evidence from the small business credit market. Journal of Banking and Finance, $35,1843-1857$.

Berkowitz, J. \& White, M. J. (2004). Bankruptcy and small firms' access to credit. Rand Journal of Economics, 35, 69-84.

Bertrand, M., Schoar, A., \& Thesmar, D. (2007). Banking Deregulation and Industry Structure: Evidence From the French Banking Reforms of 1985. Journal of Finance 62, 597628.

Blanchflower, D. \& Oswald, A. (1998). What makes an entrepreneur? Journal of Labor Economics 16, 26-60.

Brinig, M. F. \& Buckley, F. H. (1996). Market for Deadbeats. Journal of Legal Studies, 25, 201.

Brown, M., Coates, B., \& Severino, F. (2014). Personal bankruptcy protection and household debt. Working paper.

Cabral, L. \& Mata, J. (2003). On the Evolution of the Firm Size Distribution: Facts and Theory. American Economic Review, 93(4), 1075-1090.

Cerqueiro, G., Hegde, D., Penas, F., \& Seamans, R. (forthcoming). Debtor rights, credit supply, and innovation. Management Science.

Cetorelli, N. \& Strahan, P. (2006). Finance as a barrier to entry: Bank competition and industry structure in local U.S. markets. Journal of Finance 61, 437-461.

Chatterji, A. K. \& Seamans, R. C. (2012). Entrepreneurial finance, credit cards, and race. Journal of Financial Economics, 106, 182-195.

DesRoches, D., Potter, F., Santos, B., Sengmavong, A., \& Zheng, Y. (2011). Kauffman Firm Survey (KFS) fifth follow up methodology report.

Djankov, S., La Porta, R., Lopez-De-Silanes, F., \& Shleifer, A. (2002). The Regulation of Entry. Quarterly Journal of Economics, 117, 1-37 
Domowitz, I. \& Sartain, R. L. (1999). Determinants of the consumer bankruptcy decision. Journal of Finance, 54, 403-420.

Ederer, F. \& Manso, G. (2011). Incentives for Innovation: Bankruptcy, Corporate Governance, and Compensation Systems. Handbook of Law, Innovation, and Growth, Edward Elgar Publishing, 2011.

Evans, D. S. \& Jovanovic, B. (1989). An estimated model of entrepreneurial choice under liquidity constraints. Journal of Political Economy, 97, 808-827.

Fan, W. \& White, M. J. (2003). Personal bankruptcy and the level of entrepreneurial activity. Journal of Law and Economics, 46, 543-567.

Fay, S., Hurst, E., \& White, M. J. (2002). The household bankruptcy decision. American Economic Review, 92, 706-718.

Fracassi, C., Garmaise, M., Kogan, S., \& Natividad, G. (2014). Business microloans for U.S. subprime borrowers. Journal of Financial and Quantitative Analysis, forthcoming.

Gropp, R., Scholz, J. K., \& White, M. J. (1997). Personal bankruptcy and credit supply and demand. Quarterly Journal of Economics, 112, 217-251.

Gross, D. B. \& Souleles, N. S. (2002). Do liquidity constraints and interest rates matter for consumer behavior? Evidence from credit card data. Quarterly Journal of Economics, 117, 149-185.

Haltiwanger, J.C., Jarmin, R.S., \& Miranda, J. (2013). Who creates jobs? Small versus large versus young. Review of Economics and Statistics, 95, 347-361.

Holtz-Eakin, D., Joulfaian, D., \& Rosen, H. S. (1994). Sticking it out: Entrepreneurial survival and liquidity constraints. Journal of Political Economy, 102, 53-75.

Hombert, H., Schoar, A., Sraer, D., \& Thesmar, D. (2013). Can unemployment insurance spur entrepreneurial activity? Evidence from France. Working paper.

Hurst E. \& Lusardi, A. (2004) Liquidity constraints, household wealth, and entrepreneurship. Journal of Political Economy, 112, 319-47.

Hynes, R. M., Malani, A., \& Posner, E. A. (2004). The political economy of property exemption laws. Journal of Law and Economics, 47, 19-43.

Kerr, W. R. \& Nanda, R. (2009). Democratizing entry: Banking deregulations, financing constraints, and entrepreneurship. Journal of Financial Economics, 94, 124-149.

Kerr W. R. \& Nanda, R. (2010) Banking deregulations, financing constraints, and firm entry size. Journal of the European Economic Association, 8, 582-93.

Kihlstrom, R. \& Laffont, J.-J. (1979). A general equilibrium entrepreneurial theory of firm formation based on risk aversion. Journal of Political Economy, 87, 719-748.

Klapper, L., Laeven, L., \& Rajan, R. (2006). Entry Regulation as a Barrier to Entrepreneurship. Journal of Financial Economics, 82, 591-629.

von Lilienfeld-Toal, U. \& Mookherjee, D. (2016). A general equilibrium analysis of personal bankruptcy law. Economica, 83, 31-58 
Robb, A. M. \& Robinson, D. T. (2014). The capital structure decisions of new firms. Review of Financial Studies, 27, 153-179.

Shumway, T. (2001). Forecasting bankruptcy more accurately: A simple hazard model. Journal of Business, 74, 101-124.

Sufi, A. (2009). Bank lines of credit in corporate finance: An empirical analysis. Review of Financial Studies, 22, 1057-1088.

White, M. J. (2007a). Bankruptcy law. In A. M. Polinsky \& S. Shavell (eds.), Handbook of Law and Economics, 2. Elsevier.

White, M. J. (2007b). Bankruptcy reform and credit cards. Journal of Economic Perspectives, 21,175-99. 
Table 1 - Changes in state exemptions (2004-2011)

State exemptions is the sum of the homestead exemption and the personal property exemptions, which includes the following assets: jewelry, motor vehicles, cash and deposits, and the wildcard exemption. In states where individuals are allowed to choose between the state exemption and federal exemption, we selected the option that grants the highest exemption amount. In states that allow married couples to file a joint bankruptcy case, we doubled the dollar amount of the exemptions.

\begin{tabular}{|c|c|c|c|c|c|}
\hline State & Year & $\begin{array}{l}\text { Increase in } \\
\text { exemptions } \\
(\$ 000)\end{array}$ & State & Year & $\begin{array}{l}\text { Increase in } \\
\text { exemptions } \\
(\$ 000)\end{array}$ \\
\hline Delaware & 2005 & 100.0 & Maine & 2008 & 25.0 \\
\hline Indiana & 2005 & 23.4 & Minnesota & 2008 & 30.4 \\
\hline Kentucky & 2005 & 24.2 & Ohio & 2008 & 22.9 \\
\hline Nevada & 2005 & 160.0 & Rhode Island & 2008 & 16.0 \\
\hline New York & 2005 & 80.0 & South Carolina & 2008 & 11.9 \\
\hline Oklahoma & 2005 & 15.0 & California & 2009 & 25.0 \\
\hline Idaho & 2006 & 50.0 & Louisiana & 2009 & 10.0 \\
\hline Illinois & 2006 & 21.4 & North Carolina & 2009 & 33.0 \\
\hline Iowa & 2006 & 9.8 & North Dakota & 2009 & 24.3 \\
\hline Minnesota & 2006 & 0.4 & Oregon & 2009 & 12.1 \\
\hline North Carolina & 2006 & 21.0 & Vermont & 2009 & 100.0 \\
\hline Oregon & 2006 & 7.5 & Wisconsin & 2009 & 137.6 \\
\hline Rhode Island & 2006 & 100.0 & California & 2010 & 0.6 \\
\hline South Carolina & 2006 & 90.0 & Delaware & 2010 & 25.0 \\
\hline California & 2007 & 0.9 & Hawaii & 2010 & 3.7 \\
\hline Colorado & 2007 & 36.0 & Idaho & 2010 & 4.0 \\
\hline Connecticut & 2007 & 4.0 & Indiana & 2010 & 8.0 \\
\hline Hawaii & 2007 & 4.5 & Kentucky & 2010 & 3.7 \\
\hline Kentucky & 2007 & 4.5 & Maryland & 2010 & 21.6 \\
\hline Michigan & 2007 & 4.5 & Michigan & 2010 & 3.7 \\
\hline Minnesota & 2007 & 100.0 & Minnesota & 2010 & 30.4 \\
\hline Montana & 2007 & 300.0 & New Jersey & 2010 & 3.7 \\
\hline Nebraska & 2007 & 47.5 & Ohio & 2010 & 2.3 \\
\hline Nevada & 2007 & 202.0 & Pennsylvania & 2010 & 3.7 \\
\hline New Jersey & 2007 & 4.5 & South Carolina & 2010 & 4.7 \\
\hline New Mexico & 2007 & 60.0 & Tennessee & 2010 & 12.0 \\
\hline Pennsylvania & 2007 & 4.5 & Delaware & 2011 & 25.0 \\
\hline Washington & 2007 & 85.0 & Massachusetts & 2011 & 21.8 \\
\hline Alaska & 2008 & 3.2 & New York & 2011 & 210.2 \\
\hline Idaho & 2008 & 4.0 & Washington & 2011 & 8.5 \\
\hline
\end{tabular}


Table 2 - Definition of variables

Firm level data are from the Kauffman Firm Survey (KFS). State variables are obtained from various sources (see Section 5b).

\begin{tabular}{|c|c|}
\hline Variable & Definition \\
\hline \multicolumn{2}{|l|}{ Bank financing } \\
\hline Personal credit & Bank financing in the firm owner's name \\
\hline Business credit & Bank financing in the firm's name \\
\hline Personal credit card balance & Balance on personal credit cards \\
\hline Personal credit card limit & Credit limit on personal credit cards \\
\hline Other personal loans & Credit obtained via other personal loans \\
\hline \multicolumn{2}{|l|}{ Employment } \\
\hline Employees & Number of full-time employees \\
\hline Firm is employer & $=1$ if the firm has external employees \\
\hline \multicolumn{2}{|l|}{ Revenue and performance } \\
\hline Generates revenue & $=1$ if the firm generates revenue \\
\hline Revenue & Total revenue \\
\hline Efficiency & $=$ Firm revenue / Number of employees \\
\hline Failed & $=1$ if the firm is no longer in business \\
\hline \multicolumn{2}{|l|}{ State variables } \\
\hline Exemptions & Sum of the homestead and personal property exemptions \\
\hline House price changes & Change in the House Price Index (in \%) \\
\hline Median income & Median household income in the state \\
\hline Unemployment rate & Rate of unemployment in the state (in \%) \\
\hline \multicolumn{2}{|l|}{ Firm characteristics } \\
\hline Credit risk 1 (lowest risk) & $=1$ if credit score percentile is in the range $91-100$ \\
\hline Credit risk 2 & $=1$ if credit score percentile is in the range $71-90$ \\
\hline Credit risk 3 & $=1$ if credit score percentile is in the range $31-70$ \\
\hline Credit risk 4 & $=1$ if credit score percentile is in the range $11-30$ \\
\hline Credit risk 5 & $=1$ if credit score percentile is in the range $1-10$ \\
\hline Limited liability & $=1$ if firm is incorporated \\
\hline \multicolumn{2}{|l|}{ Owner characteristics } \\
\hline Experience & Work experience in industry (in years) \\
\hline Other businesses & Number of other businesses started by the firm owner \\
\hline Other businesses in industry & $=1$ if owner started other businesses in same industry \\
\hline Minority & $=1$ if primary owner is non-white \\
\hline High school & $=1$ if education level is high school diploma \\
\hline College degree & $=1$ if education level is college or graduate degree \\
\hline \multicolumn{2}{|l|}{ Owner wealth } \\
\hline Low wealth & $=1$ if net worth $<\$ 50,000$ \\
\hline Mid wealth & $=1$ if net worth is between $\$ 50,001$ and $\$ 250,000$ \\
\hline High wealth & $=1$ if net worth $>\$ 250,000$ \\
\hline
\end{tabular}


Table 3 - Summary statistics by wealth group

Data are from the Kauffman Firm Survey (KFS) for the year 2004. State variables are obtained from various sources (see Section $5 \mathrm{~b}$ ). We assign a value of $\$ 1$ million to states with unlimited exemptions. Low wealth refers to entrepreneurs with wealth below $\$ 50,000$, and High wealth refers to entrepreneurs with wealth above $\$ 250,000$. The number of firms in each wealth group is: 513 (Low wealth), 1629 (Mid wealth), and 2459 (High wealth). See the Internet Appendix for details on how we assign entrepreneurs to the different wealth groups. The statistics displayed account for the KFS sampling weights.

\begin{tabular}{|c|c|c|c|c|c|c|}
\hline \multirow[t]{2}{*}{ Wealth group: } & \multicolumn{2}{|c|}{ Low wealth } & \multicolumn{2}{|c|}{ Mid wealth } & \multicolumn{2}{|c|}{ High wealth } \\
\hline & Mean & S.d. & Mean & S.d. & Mean. & S.d. \\
\hline \multicolumn{7}{|l|}{ Bank financing (in logs) } \\
\hline Personal credit & 4.4 & 4.55 & 5.16 & 4.88 & 5.23 & 5.03 \\
\hline Business credit & 0.23 & 1.38 & 1.51 & 3.59 & 1.71 & 3.93 \\
\hline Personal credit card balance & 2.58 & 3.73 & 2.63 & 3.95 & 2.53 & 3.97 \\
\hline Personal credit card limit & 3.84 & 4.33 & 4.37 & 4.66 & 4.22 & 4.79 \\
\hline Other personal loans & 1.42 & 3.41 & 1.92 & 4.08 & 2.06 & 4.29 \\
\hline \multicolumn{7}{|l|}{ Employment } \\
\hline Employees (log) & 0.37 & 0.59 & 0.51 & 0.76 & 0.60 & 0.86 \\
\hline Firm is employer & 0.33 & 0.47 & 0.4 & 0.49 & 0.42 & 0.49 \\
\hline \multicolumn{7}{|l|}{ Revenue and performance } \\
\hline Generates revenue & 0.58 & 0.49 & 0.66 & 0.47 & 0.61 & 0.49 \\
\hline Revenue (log) & 5.49 & 4.88 & 6.79 & 5.11 & 6.46 & 5.43 \\
\hline Efficiency $(\log )$ & 1.42 & 1.59 & 1.96 & 1.83 & 1.90 & 1.91 \\
\hline \multicolumn{7}{|l|}{ State variables } \\
\hline Exemptions (\$000) & 232.2 & 375.6 & 272.7 & 402.4 & 235.3 & 367.4 \\
\hline House price index & 0.08 & 0.05 & 0.07 & 0.04 & 0.08 & 0.05 \\
\hline Median state income $(\log )$ & 10.71 & 0.12 & 10.7 & 0.12 & 10.72 & 0.12 \\
\hline State unemployment rate & 5.57 & 0.81 & 5.46 & 0.80 & 5.52 & 0.84 \\
\hline \multicolumn{7}{|l|}{ Firm characteristics } \\
\hline Credit risk 1 (lowest risk) & 0.00 & 0.00 & 0.00 & 0.06 & 0.01 & 0.08 \\
\hline Credit risk 2 & 0.03 & 0.16 & 0.07 & 0.25 & 0.05 & 0.22 \\
\hline Credit risk 3 & 0.26 & 0.44 & 0.33 & 0.47 & 0.39 & 0.49 \\
\hline Credit risk 4 & 0.35 & 0.48 & 0.33 & 0.47 & 0.25 & 0.44 \\
\hline Credit risk 5 & 0.09 & 0.28 & 0.05 & 0.22 & 0.04 & 0.19 \\
\hline Limited liability firm & 0.18 & 0.38 & 0.51 & 0.50 & 0.77 & 0.42 \\
\hline \multicolumn{7}{|l|}{ Owner characteristics } \\
\hline Experience & 7.21 & 6.31 & 13.64 & 10.46 & 12.23 & 11.17 \\
\hline Other businesses started & 0.45 & 0.99 & 0.67 & 1.24 & 1.28 & 3.46 \\
\hline Other businesses in industry & 0.09 & 0.28 & 0.15 & 0.36 & 0.21 & 0.40 \\
\hline Minority & 0.52 & 0.50 & 0.04 & 0.21 & 0.17 & 0.37 \\
\hline High school & 0.50 & 0.50 & 0.41 & 0.49 & 0.26 & 0.44 \\
\hline College degree & 0.42 & 0.49 & 0.58 & 0.49 & 0.71 & 0.45 \\
\hline
\end{tabular}




\section{Table 4 - Bank financing: Personal credit and Business credit}

The table displays coefficients from panel regressions of the $\log$ of one plus the dollar amounts of Personal credit and Business credit. Exemptions is the sum of the homestead exemption and the personal property exemptions, which includes the following assets: jewelry, motor vehicles, cash and deposits, and the wildcard exemption. Exemption values are in million of dollars. Low wealth refers to entrepreneurs with wealth below $\$ 50,000$, and High wealth refers to entrepreneurs with wealth above $\$ 250,000$. Data are from the Kauffman Firm Survey (KFS) for the years 2004-2011. Our estimation takes into account the KFS sampling weights. Standard errors (in parentheses) are clustered at the state level. The symbols $* * *, * *$, and $*$ indicate significance at the $1 \%, 5 \%$, and $10 \%$ levels, respectively.

\begin{tabular}{|c|c|c|c|c|c|c|}
\hline & \multicolumn{3}{|c|}{ Personal credit $(\log )$} & \multicolumn{3}{|c|}{ Business credit (log) } \\
\hline & $(1)$ & $(2)$ & (3) & $(4)$ & (5) & (6) \\
\hline \multicolumn{7}{|l|}{ Exemptions } \\
\hline Exemptions ( $\$ 1$ million) & $\begin{array}{l}-5.66^{* *} \\
(-2.08)\end{array}$ & $\begin{array}{l}-6.41^{* *} \\
(-2.33)\end{array}$ & & $\begin{array}{c}-2.20 \\
(-1.12)\end{array}$ & $\begin{array}{c}-1.36 \\
(-0.64)\end{array}$ & \\
\hline Exemptions $\times$ LowWealth & $\begin{array}{c}7.38 \\
(1.48)\end{array}$ & $\begin{array}{c}8.56^{*} \\
(1.67)\end{array}$ & $\begin{array}{c}7.47 \\
(1.43)\end{array}$ & $\begin{array}{c}4.56 \\
(1.64)\end{array}$ & $\begin{array}{c}2.74 \\
(0.88)\end{array}$ & $\begin{array}{l}5.12^{*} \\
(1.91)\end{array}$ \\
\hline Exemptions $\times$ HighWealth & $\begin{array}{l}6.60^{* *} \\
(2.20)\end{array}$ & $\begin{array}{l}7.39^{* *} \\
(2.51)\end{array}$ & $\begin{array}{l}6.42^{* *} \\
(2.01)\end{array}$ & $\begin{array}{c}0.85 \\
(0.29)\end{array}$ & $\begin{array}{c}0.41 \\
(0.13)\end{array}$ & $\begin{array}{c}1.16 \\
(0.40)\end{array}$ \\
\hline \multicolumn{7}{|l|}{ Firm controls } \\
\hline Credit risk 1 & $\begin{array}{l}1.19^{* * * *} \\
(5.13)\end{array}$ & $\begin{array}{l}1.19^{* * * *} \\
(5.11)\end{array}$ & $\begin{array}{l}1.21^{* * * *} \\
(5.03)\end{array}$ & $\begin{array}{l}0.88^{* * * *} \\
(5.81)\end{array}$ & $\begin{array}{c}0.88^{* * * *} \\
(5.87)\end{array}$ & $\begin{array}{c}0.89^{* * * *} \\
(5.59)\end{array}$ \\
\hline Credit risk 2 & $\begin{array}{c}0.98^{* * *} \\
(6.70)\end{array}$ & $\begin{array}{c}0.97^{* * *} \\
(6.58)\end{array}$ & $\begin{array}{l}1.00^{* * *} \\
(6.61)\end{array}$ & $\begin{array}{c}0.48^{* * *} \\
(5.67)\end{array}$ & $\begin{array}{c}0.49^{* * *} \\
(5.70)\end{array}$ & $\begin{array}{l}0.46^{* * *} \\
(5.43)\end{array}$ \\
\hline Credit risk 3 & $\begin{array}{c}0.81^{* * *} \\
(7.35)\end{array}$ & $\begin{array}{c}0.81^{* * *} \\
(7.27)\end{array}$ & $\begin{array}{c}0.82^{* * *} \\
(7.19)\end{array}$ & $\begin{array}{l}0.41^{* * *} \\
(6.68)\end{array}$ & $\begin{array}{c}0.41^{* * * *} \\
(6.75)\end{array}$ & $\begin{array}{c}0.40^{* * * *} \\
(6.45)\end{array}$ \\
\hline Credit risk 4 & $\begin{array}{c}0.48^{* * * *} \\
(4.21)\end{array}$ & $\begin{array}{c}0.48^{\text {***** }} \\
(4.25)\end{array}$ & $\begin{array}{c}0.49^{* * * *} \\
(4.28)\end{array}$ & $\begin{array}{l}0.22^{* * * *} \\
(3.83)\end{array}$ & $\begin{array}{l}0.22^{* * * *} \\
(4.04)\end{array}$ & $\begin{array}{c}0.21^{\text {**** }} \\
(3.60)\end{array}$ \\
\hline Credit risk 5 & $\begin{array}{c}-0.10 \\
(-0.64)\end{array}$ & $\begin{array}{c}-0.11 \\
(-0.69)\end{array}$ & $\begin{array}{c}-0.13 \\
(-0.80)\end{array}$ & $\begin{array}{c}0.081 \\
(0.89)\end{array}$ & $\begin{array}{c}0.086 \\
(0.93)\end{array}$ & $\begin{array}{l}0.097 \\
(1.02)\end{array}$ \\
\hline Firm FE & Yes & Yes & Yes & Yes & Yes & Yes \\
\hline Year FE & Yes & No & No & Yes & No & No \\
\hline Wealth group $\times$ Year FE & No & Yes & Yes & No & Yes & Yes \\
\hline State controls & Yes & Yes & No & Yes & Yes & No \\
\hline State $\times$ Year FE & No & No & Yes & No & No & Yes \\
\hline Number of observations & 30,318 & 30,318 & 30,318 & 30,318 & 30,318 & 30,318 \\
\hline R-squared & 0.058 & 0.058 & 0.073 & 0.011 & 0.012 & 0.029 \\
\hline
\end{tabular}




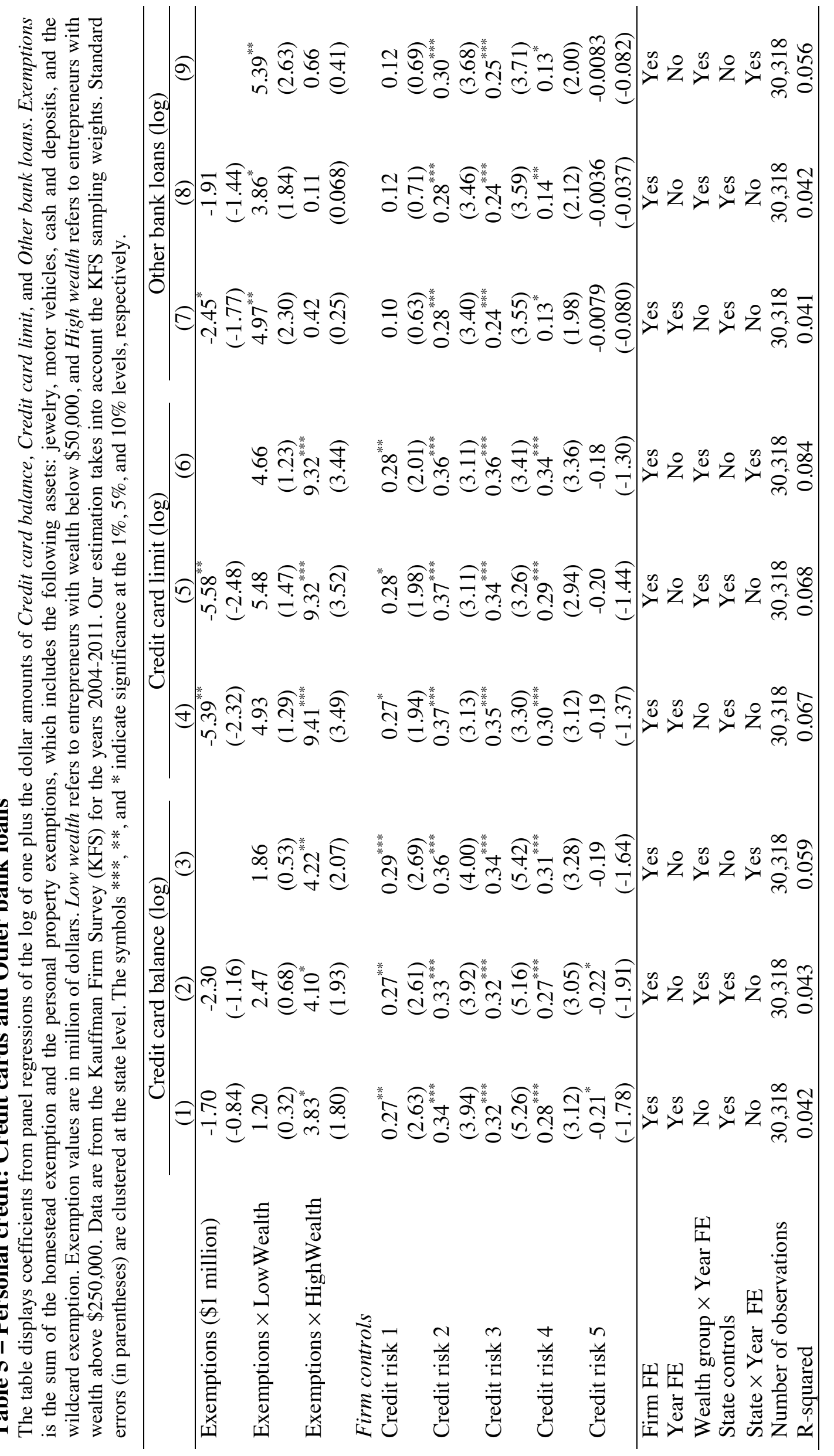




\section{Table 6 - Firm employment}

The table displays coefficients from panel regressions of the log of the number employees (including the firm owner) and of the dummy Has employees. Exemptions is the sum of the homestead exemption and the personal property exemptions, which includes the following assets: jewelry, motor vehicles, cash and deposits, and the wildcard exemption. Exemption values are in million of dollars. Low wealth refers to entrepreneurs with wealth below $\$ 50,000$, and High wealth refers to entrepreneurs with wealth above \$250,000. Data are from the Kauffman Firm Survey (KFS) for the years 2004-2011. Our estimation takes into account the KFS sampling weights. Standard errors (in parentheses) are clustered at the state level. The symbols $* * *, * *$, and * indicate significance at the $1 \%, 5 \%$, and $10 \%$ levels, respectively.

\begin{tabular}{|c|c|c|c|c|c|c|}
\hline & \multicolumn{3}{|c|}{ Employees (log) } & \multicolumn{3}{|c|}{ Has employees $(0 / 1)$} \\
\hline & (1) & (2) & (3) & (4) & $(5)$ & (6) \\
\hline \multicolumn{7}{|l|}{ Exemptions } \\
\hline \multirow[t]{2}{*}{ Exemptions ( $\$ 1$ million) } & -0.49 & -0.42 & & $-0.51^{* *}$ & $-0.47^{* *}$ & \\
\hline & $(-1.25)$ & $(-1.04)$ & & $(-2.17)$ & $(-2.02)$ & \\
\hline \multirow[t]{2}{*}{ Exemptions $\times$ LowWealth } & $1.01^{*}$ & 0.79 & 0.99 & $0.99^{* * *}$ & $0.87^{* *}$ & $0.95^{* *}$ \\
\hline & $(1.86)$ & $(1.42)$ & (1.64) & $(2.78)$ & $(2.44)$ & $(2.58)$ \\
\hline \multirow[t]{2}{*}{ Exemptions $\times$ HighWealth } & 0.77 & 0.79 & 0.73 & $0.60^{*}$ & $0.61^{*}$ & $0.55^{*}$ \\
\hline & $(1.31)$ & $(1.34)$ & (1.19) & $(1.78)$ & $(1.87)$ & $(1.65)$ \\
\hline Firm controls & $0.27^{* * *}$ & $0.28^{* * *}$ & $0.27^{* * *}$ & $0.14^{* * *}$ & $0.15^{* * *}$ & $0.14^{* * *}$ \\
\hline \multirow[t]{2}{*}{ Credit risk 1} & $(9.24)$ & $(9.33)$ & $(8.95)$ & $(8.97)$ & $(9.12)$ & $(8.62)$ \\
\hline & $0.19^{* * *}$ & $0.20^{* * * *}$ & $0.19^{* * * *}$ & $0.10^{* * * *}$ & $0.11^{* * * *}$ & $0.10^{* * * *}$ \\
\hline \multirow[t]{2}{*}{ Credit risk 2} & $(9.42)$ & $(9.35)$ & $(8.87)$ & $(9.16)$ & $(9.24)$ & $(8.86)$ \\
\hline & $0.12^{* * *}$ & $0.12^{* * * *}$ & $0.12^{* * *}$ & $0.066^{* * *}$ & $0.066^{* * *}$ & $0.066^{* * *}$ \\
\hline \multirow[t]{2}{*}{ Credit risk 3} & $(7.43)$ & $(7.58)$ & $(7.32)$ & $(7.31)$ & $(7.36)$ & $(7.23)$ \\
\hline & $0.082^{* * *}$ & $0.085^{* * *}$ & $0.088^{* * *}$ & $0.048^{* * *}$ & $0.049^{* * *}$ & $0.051^{* * * *}$ \\
\hline \multirow[t]{2}{*}{ Credit risk 4} & $(4.44)$ & $(4.41)$ & $(4.91)$ & $(3.71)$ & $(3.78)$ & $(3.84)$ \\
\hline & 0.00081 & 0.0013 & 0.0048 & 0.012 & 0.013 & 0.012 \\
\hline Credit risk 5 & $(0.046)$ & $(0.070)$ & $(0.27)$ & $(1.06)$ & $(1.10)$ & $(1.06)$ \\
\hline Firm FE & Yes & Yes & Yes & Yes & Yes & Yes \\
\hline Year FE & Yes & No & No & Yes & No & No \\
\hline Wealth group $\times$ Year FE & No & Yes & Yes & No & Yes & Yes \\
\hline State controls & Yes & Yes & No & Yes & Yes & No \\
\hline State $\times$ Year FE & No & No & Yes & No & No & Yes \\
\hline Number of observations & 30,318 & 30,318 & 30,318 & 30,318 & 30,318 & 30,318 \\
\hline R-squared & 0.033 & 0.034 & 0.051 & 0.045 & 0.046 & 0.063 \\
\hline
\end{tabular}


Table 7 - Firm revenue and efficiency

The table displays coefficients from panel regressions of the dummy Generates revenue and of the log of one plus Efficiency, which equals revenue per employee. Exemptions is the sum of the homestead exemption and the personal property exemptions, which includes the following assets: jewelry, motor vehicles, cash and deposits, and the wildcard exemption. Exemption values are in million of dollars. Low wealth refers to entrepreneurs with wealth below $\$ 50,000$, and High wealth refers to entrepreneurs with wealth above \$250,000. Data are from the Kauffman Firm Survey (KFS) for the years 2004-2011. Our estimation takes into account the KFS sampling weights. Standard errors (in parentheses) are clustered at the state level. The symbols ***, **, and * indicate significance at the $1 \%, 5 \%$, and $10 \%$ levels, respectively.

\begin{tabular}{|c|c|c|c|c|c|c|}
\hline & \multicolumn{3}{|c|}{ Generates revenue $(0 / 1)$} & \multicolumn{3}{|c|}{ Efficiency $(\log )$} \\
\hline & $(1)$ & (2) & (3) & (4) & (5) & (6) \\
\hline \multicolumn{7}{|l|}{ Exemptions } \\
\hline Exemptions (\$1 million) & $\begin{array}{l}-0.73^{* * * *} \\
(-3.55)\end{array}$ & $\begin{array}{l}-0.66^{* * *} \\
(-2.88)\end{array}$ & & $\begin{array}{l}-4.08^{* * * *} \\
(-4.37)\end{array}$ & $\begin{array}{l}-3.26^{* * *} \\
(-3.39)\end{array}$ & \\
\hline Exemptions $\times$ LowWealth & $\begin{array}{l}1.36^{* * * *} \\
(3.88)\end{array}$ & $\begin{array}{l}1.21^{* * * *} \\
(3.19)\end{array}$ & $\begin{array}{l}1.34^{* * * *} \\
(3.58)\end{array}$ & $\begin{array}{l}7.69^{* * * *} \\
(5.06)\end{array}$ & $\begin{array}{l}5.87^{* * * *} \\
(3.90)\end{array}$ & $\begin{array}{l}7.76^{\text {**** }} \\
(4.47)\end{array}$ \\
\hline Exemptions $\times$ HighWealth & $\begin{array}{c}0.33 \\
(0.96)\end{array}$ & $\begin{array}{c}0.26 \\
(0.73)\end{array}$ & $\begin{array}{c}0.33 \\
(0.93)\end{array}$ & $\begin{array}{c}2.18 \\
(1.64)\end{array}$ & $\begin{array}{c}1.76 \\
(1.28)\end{array}$ & $\begin{array}{c}2.33 \\
(1.62)\end{array}$ \\
\hline Firm controls & $0.094^{* * *}$ & $0.094^{* * *}$ & $0.093^{* * *}$ & $0.42^{* * *}$ & $0.42^{* * *}$ & $0.41^{\text {*** }}$ \\
\hline Credit risk 1 & $\begin{array}{c}(5.29) \\
0.067^{* * *}\end{array}$ & $\begin{array}{c}(5.29) \\
0.066^{* * *}\end{array}$ & $\begin{array}{c}(5.09) \\
0.067^{* * *}\end{array}$ & $\begin{array}{c}(4.93) \\
0.29^{* * *}\end{array}$ & $\begin{array}{l}(5.03) \\
0.29^{* * *}\end{array}$ & $\begin{array}{l}(4.55) \\
0.29^{* * * *}\end{array}$ \\
\hline Credit risk 2 & $\begin{array}{c}(5.76) \\
0.058^{* * *}\end{array}$ & $\begin{array}{c}(5.63) \\
0.058^{* * *}\end{array}$ & $\begin{array}{c}(5.72) \\
0.059^{* * * *}\end{array}$ & $\begin{array}{l}(6.14) \\
0.27^{* * *}\end{array}$ & $\begin{array}{l}(6.17) \\
0.27^{* * *}\end{array}$ & $\begin{array}{l}(5.99) \\
0.27^{* * *}\end{array}$ \\
\hline Credit risk 3 & $\begin{array}{c}(6.10) \\
0.055^{* * *}\end{array}$ & $\begin{array}{c}(5.97) \\
0.055^{* * *}\end{array}$ & $\begin{array}{c}(5.87) \\
0.054^{* * *}\end{array}$ & $\begin{array}{l}(7.32) \\
0.16^{* * *}\end{array}$ & $\begin{array}{l}(7.37) \\
0.16^{* * *}\end{array}$ & $\begin{array}{l}(7.23) \\
0.16^{* * *}\end{array}$ \\
\hline Credit risk 4 & $\begin{array}{c}(6.55) \\
0.047^{* * *} \\
(3.04)\end{array}$ & $\begin{array}{c}(6.47) \\
0.047^{* * *} \\
(3.01)\end{array}$ & $\begin{array}{c}(6.38) \\
0.046^{* * *} \\
(3.03)\end{array}$ & $\begin{array}{l}(4.39) \\
0.21^{* * *} \\
(3.97)\end{array}$ & $\begin{array}{l}(4.52) \\
0.21^{* * * *} \\
(4.01)\end{array}$ & $\begin{array}{c}(4.33) \\
0.21^{\text {**** }} \\
(3.92)\end{array}$ \\
\hline Firm FE & Yes & Yes & Yes & Yes & Yes & Yes \\
\hline Year FE & Yes & No & No & Yes & No & No \\
\hline Wealth group $\times$ Year FE & No & Yes & Yes & No & Yes & Yes \\
\hline State controls & Yes & Yes & No & Yes & Yes & No \\
\hline State $\times$ Year FE & No & No & Yes & No & No & Yes \\
\hline Number of observations & 30,318 & 30,318 & 30,318 & 30,318 & 30,318 & 30,318 \\
\hline R-squared & 0.323 & 0.323 & 0.335 & 0.277 & 0.277 & 0.288 \\
\hline
\end{tabular}




\section{Table 8 - Firm failure}

The table displays coefficients from a logit regression of firm failure. Exemptions is the sum of the homestead exemption and the personal property exemptions, which includes the following assets: jewelry, motor vehicles, cash and deposits, and the wildcard exemption. Exemption values are in million of dollars. Low wealth refers to entrepreneurs with wealth below $\$ 50,000$, and High wealth refers to entrepreneurs with wealth above $\$ 250,000$. Firm controls include legal form dummies and industry dummies. Owner controls include the variables Experience, Other businesses, Other businesses in industry, Minority, High school, and College degree (see Table 2 for details). Data are from the Kauffman Firm Survey (KFS) for the years 2004-2011. Our estimation takes into account the KFS sampling weights. Standard errors (in parentheses) are clustered at the state level. The symbols $* * *, * *$, and $*$ indicate significance at the $1 \%, 5 \%$, and $10 \%$ levels, respectively.

\begin{tabular}{lc}
\hline & Bankruptcy $(0 / 1)$ \\
\cline { 2 - 2 } & $(1)$ \\
\hline Exemptions & $2.75^{* * *}$ \\
Exemptions (\$1 million) & $(2.87)$ \\
Exemptions $\times$ LowWealth & $-2.86^{*}$ \\
& $(-1.80)$ \\
Exemptions $\times$ HighWealth & $-2.09^{*}$ \\
& $(-1.66)$ \\
Firm controls & \\
Credit risk 1 & \\
& $-1.87^{* * *}$ \\
Credit risk 2 & $-11.8)$ \\
& $-1.40^{* * *}$ \\
Credit risk 3 & $(-15.0)$ \\
& $-0.98^{* * *}$ \\
Credit risk 4 & $(-16.6)$ \\
& $-0.83^{* * *}$ \\
Credit risk 5 & $(-12.9)$ \\
& $-0.46^{* * *}$ \\
& $(-5.50)$ \\
\hline State fixed effects & Yes \\
State controls & Yes \\
Fwner controls & Yes \\
Number of observations & 30,318 \\
\hline
\end{tabular}




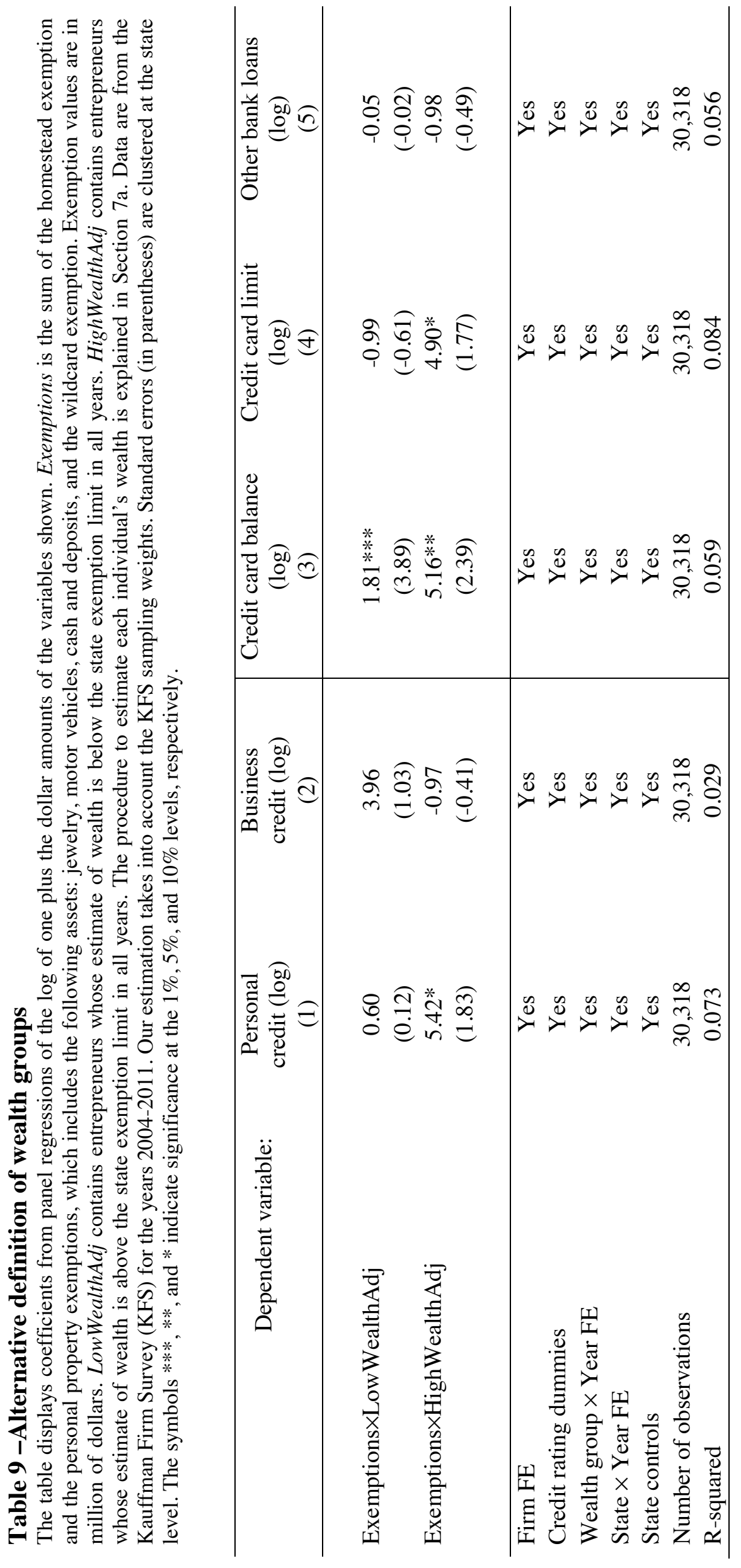




\section{Internet Appendix for \\ "How does personal bankruptcy law affect start-ups?"}

Table of contents

Section A - State exemption laws

Section B - Instrumenting for the wealth groups

Table B1 - Variables used to predict the wealth groups

Table B2 - Predictive model

Section C - Differential pre-trends and trends

Table C1 - Personal credit and Business credit (Table 4)

Table C2 - Personal credit: Credit cards and Other bank loans (Table 5)

Table C3 - Firm employment (Table 6)

Table C4 - Firm revenue and efficiency (Table 7)

Section D - Nonparametric standard errors

Table D1 - Personal credit and Business credit (Table 4)

Table D2 - Personal credit: Credit cards and Other bank loans (Table 5)

Table D3 - Firm employment (Table 6)

Table D4 - Firm revenue and efficiency (Table 7)

Table D5 - Firm failure (Table 8)

Section $\mathbf{E}$ - The role of firm age

Table E1 - Personal credit and Business credit (Table 4)

Section F - Reported versus predicted wealth

Table F1 - Personal credit and Business credit (Table 4)

Table F2 - Personal credit: Credit cards and Other bank loans (Table 5)

Table F3 - Firm employment (Table 6)

Table F4 - Firm revenue and efficiency (Table 7)

Table F5 - Firm failure (Table 8)

Appendix G - Right censoring

Table G1 - Personal credit and Business credit (Table 4) 


\section{Section A - State exemption laws}

For some states we were able to collect documentation that helps to understand the motivation of the state laws that amended exemption limits. We obtained this evidence from various sources including comments, reports, and public hearings on the proposed bills. According to the evidence collected, the proposals of an increase in the exemption limits were urged by three arguments.

The first and main argument is the gap between the homestead exemption value and current home prices. Proponents of the increase in the exemption levels argued that, since in most states the exemption levels are not updated regularly, sharp increases in housing prices and inflation together eroded the homestead's purpose of protecting home ownership. In most cases the discussion surrounding the approval of the bill focused indeed on the mode of determining a fair homestead value that reflected current prices. For instance, such a discussion is present in "Senate Bill 70", which proposed to increase the homestead exemption in Nevada from $\$ 125,000$ to $\$ 200,000{ }^{1}$ We note that the discussion was promoted by the Southern Nevada Homebuilders Association and by the local Realtors Association. These lobbyists based their case on the sharp increase in home prices in Las Vegas.

A second argument often used is that skyrocketing medical expenses increased the need of such protection for medically indebted households. This argument is consistent with the evidence in Domowitz and Sartain (1999), who find medical debt to be one of the most important determinants of the consumer bankruptcy decision. The concern of soaring medical expenses is highlighted, for example, in the report on bill HB1805 to raise the homestead exemption in Washington from $\$ 40,000$ to

\footnotetext{
${ }^{1}$ See comment by one attorney at http://law.unlv.edu/sites/default/files/SB70.pdf, accessed 16 March 2016
} 
$\$ 100,000$, and in the transcripts on proposal LB237 to increase the homestead exemption in Nebraska from $\$ 12,500$ to $\$ 60,000 .^{2}$

The third argument is that the state's exemption level is much lower than the exemptions offered by other states. Brinig and Buckley (1996) argue that states use bankruptcy law to compete for "deadbeats," i.e., agents who cross state lines to avoid repayment of debts. These "deadbeats" make desirable immigrants, since they bring to the state assets to protect. For instance, the fact that Nebraska is surrounded by three states that have unlimited homestead exemptions (South Dakota, Iowa, and Kansas) may have contributed decisively to the increase in homestead exemption from $\$ 12,500$ to $\$ 60,000$, effective on January 2007.

Overall, it seems that the main purpose of increasing homestead exemption levels was to restore a reasonable level of insurance to debtors, which had been eroded by increasing home price values and medical costs. It is important to note that the discussion in the majority of the bills we examined was overly influenced by a well-identified group with clear private interests in litigation. The main promoters of the increase in exemption levels were attorneys, law firms, and local bar associations. Hynes et al. (2004) argue that lawyers have strong incentives to lobby in favor of generous debtor protection, as this increases bankruptcy and debt-related litigation. On the opposite side sat representatives of local associations of banks and collectors.

2 See http://apps.leg.wa.gov/documents/billdocs/2007-08/Pdf/Bill\%20Reports/House/1805.HBR.pdf and http://www.legislature.ne.gov/FloorDocs/100/PDF/Transcripts/Judiciary/2007-01-24.pdf, both accessed 16 March 2016. 


\section{Section B - Instrumenting for the wealth groups}

The entrepreneur's wealth group is a key variable in our analysis. Unfortunately, the KFS provides information about entrepreneurial wealth only in its fourth follow-up survey (2008). Using this wealth measure directly in our analysis poses several problems. First, several firms went out of business before 2008, greatly reducing the sample size. In particular, information about net worth is available only for 2,650 firms (or $53 \%$ of the initial sample). Second, the fact that wealth is measured as of 2008 implies that it could be in part driven by the firm outcomes we analyze (i.e., firm financing and performance).

To overcome these limitations, we estimate a predictive model of the entrepreneur's wealth group based on several firm and owner characteristics. The predictive model allows us to obtain wealth estimates for all firms in the sample (as long as information on the predictors is not missing), thus addressing the missing data problem. In addition, the model predicts an entrepreneur's wealth group using only pre-determined characteristics (measured as of 2004 or before), which makes our wealth measure fairly exogenous with respect to subsequent firm outcomes. We use three types of variables to estimate the wealth groups: (i) firm level characteristics (legal form and industry), (ii) zip-code level characteristics from the 2000 Census (proportion of whites, average house value, and average income per household), and (iii) characteristics of the entrepreneur (experience, education, age, gender, and race). Table B1 lists all variables used to predict the entrepreneur's wealth interval.

We obtain predictions for the entrepreneurs' wealth groups as follows. The 2008 KFS reports entrepreneur wealth divided into five intervals: (i) \$0 or less, (ii) \$1 to $\$ 50,000$, (iii) $\$ 50,001$ to $\$ 100,000$, (iv) $\$ 100,001$ to $\$ 250,000$, and (v) $\$ 250,001$ and up. Because some of these intervals have relatively few observations, we 
aggregate them into three wealth groups: Low wealth (includes entrepreneurs with wealth up to \$50,000), Mid wealth (includes entrepreneurs with wealth between $\$ 50,001$ and $\$ 250,000$ ), and High wealth (includes entrepreneurs with wealth above $\$ 250,000)$. To obtain predicted wealth, we estimate separate cross-sectional probit regressions for the three wealth groups conditional on the covariates listed in Table B1. Table B2 displays the results obtained. As expected, wealthier entrepreneurs live in neighborhoods with higher house values and with higher proportion of whites. In addition, they have more business experience, are older, and more educated. Results are similar if we estimate binary logit regressions or an ordinal logit model.

Following the estimation procedure, we compute the matrix containing the predicted probabilities of an entrepreneur falling into each of the three wealth intervals (Low wealth, Mid wealth, and High wealth). We normalize the predicted probabilities such that they add up to one and scale each probability by the group average, so that the predicted probabilities refer to the average entrepreneurs within each wealth category.

In our regressions we use these predicted probabilities (interacted with the exemptions variable) as an "instrument" for the entrepreneur's wealth group. In some specific cases we need to assign an entrepreneur to a particular wealth group (in a binary rather than in a probabilistic way). Specifically, we need to do it: (i) when we provide descriptive statistics for each wealth group (in Table 3), and (ii) when we estimate models that include fixed effects for the calendar year interacted with the wealth groups. In those cases, we assign entrepreneurs to a given wealth group using a cut-off of $40 \%$ (for instance, if the predicted probability of an entrepreneur being Low wealth is at least 0.4 and if each of the two other predicted probabilities are lower than this value, we assign the entrepreneur to the Low wealth group). Using this cut-off, we 
assign $11 \%$ of entrepreneurs to the low wealth group, $35 \%$ to the mid wealth group, and $53 \%$ to the high wealth group. An alternative procedure is to choose cut-offs in a way to ensure that the distribution of the wealth groups is similar to the one based on reported wealth in 2008. Our results with this alternative approach are similar. We note that using a higher cut-off (say, of 0.5) would shrink even further the sample size of the low wealth group.

Table 3 shows that the wealth groups we obtain with this procedure are very reasonable in terms of their observable characteristics. For example, wealthier entrepreneurs found larger companies on average, are more likely to incorporate their companies, have more working experience in the industry, and are more educated, while low wealth entrepreneurs are more likely to belong to minority groups. 
Table B1 - Predictors of the firm owner's wealth group

The table lists all variables used to predict the wealth group of firm owners. All variables are measured as of 2004.

\begin{tabular}{ll}
\hline Variable & Description \\
\hline ZIP-level information &
\end{tabular}

Proportion of whites Proportion of whites in the firm's Zip code (2000 Census)

Average home value Average home value in the firm's ZIP code (2000 Census)

Average income

Average income per household in the firm's ZIP code (2000

Census).

Owner demographics

Experience

Years of work experience in the industry.

Other businesses

Number of other businesses started.

Other businesses in industry

Age

$=1$ if primary owner started other businesses in same industry

Female

Dummies: 18-24, 25-34, 35-44, 45-54, 55-64, 65-74, and 75 or more.

Minority

$=1$ if the owner's gender is female.

$=1$ if the owner's race is non-white

Dummies: Less than $9^{\text {th }}$ grade; Some high school, but no diploma; High school graduate; Technical, trade, or

Education vocational degree; Some college, but no degree; Associate's degree; Bachelor's degree; Some graduate school but no degree; Master's degree; Professional school or doctorate.

Firm characteristics

Legal form

Dummies: Sole Proprietorship; Limited Liability Company;

Industry

S-Corporation; C-Corporation; General Partnership; Limited Partnership; Other. One digit SIC codes 
Table B2 - Predicting wealth groups

The table provides coefficient estimates from probit regressions of the entrepreneurs' wealth categories. Low wealth refers to entrepreneurs with wealth below $\$ 50,000$, Mid wealth refers to entrepreneurs with wealth between $\$ 50,000$ and $\$ 250,000$, and High wealth refers to entrepreneurs with wealth above $\$ 250,000$. All regressions include legal form dummies (7) and industry dummies (9). Data are from the Kauffman Firm Survey (KFS). Our estimation takes into account the KFS sampling weights. Standard errors (in parentheses) are clustered at the state level. The symbols ***, **, and $*$ indicate significance at the $1 \%, 5 \%$, and $10 \%$ levels, respectively.

\begin{tabular}{|c|c|c|c|}
\hline Wealth group: & $\begin{array}{c}(1) \\
\text { Low wealth }\end{array}$ & $\begin{array}{c}(2) \\
\text { Mid wealth }\end{array}$ & $\begin{array}{c}(3) \\
\text { High wealth }\end{array}$ \\
\hline \multicolumn{4}{|l|}{ Zip-level information } \\
\hline Proportion of whites & $\begin{array}{l}-0.031 \\
(-0.62)\end{array}$ & $\begin{array}{c}0.15^{* * * *} \\
(3.22)\end{array}$ & $\begin{array}{c}0.40^{* * * *} \\
(8.31)\end{array}$ \\
\hline Average home value & $\begin{array}{c}-0.0053 \\
(-0.23)\end{array}$ & $\begin{array}{c}-0.24 * * * \\
(-10.7)\end{array}$ & $\begin{array}{c}0.21 * * * \\
(10.4)\end{array}$ \\
\hline Average income & $\begin{array}{c}-0.15 * * * \\
(-4.33)\end{array}$ & $\begin{array}{c}0.12 * * * \\
(3.57)\end{array}$ & $\begin{array}{l}-0.028 \\
(-0.93)\end{array}$ \\
\hline \multicolumn{4}{|l|}{ Owner demographics } \\
\hline Experience & $\begin{array}{c}-0.0061 * * * \\
(-6.19)\end{array}$ & $\begin{array}{c}0.0015^{*} \\
(1.72)\end{array}$ & $\begin{array}{c}0.0099 * * * \\
(12.6)\end{array}$ \\
\hline Other businesses & $\begin{array}{c}0.0011 \\
(0.33)\end{array}$ & $\begin{array}{c}-0.0070^{*} \\
(-1.90)\end{array}$ & $\begin{array}{c}-0.0083 * * * \\
(-3.13)\end{array}$ \\
\hline Other businesses in industry & $\begin{array}{c}-0.096 * * * \\
(-3.76)\end{array}$ & $\begin{array}{l}-0.020 \\
(-0.90)\end{array}$ & $\begin{array}{c}0.060 * * * \\
(2.93)\end{array}$ \\
\hline Age $25-34$ & $\begin{array}{c}-0.24 * * * \\
(-3.85)\end{array}$ & $\begin{array}{c}0.68 * * * \\
(7.52)\end{array}$ & $\begin{array}{l}0.047 \\
(0.51)\end{array}$ \\
\hline Age $35-44$ & $\begin{array}{c}-0.36 * * * \\
(-5.69)\end{array}$ & $\begin{array}{c}0.77 * * * \\
(8.55)\end{array}$ & $\begin{array}{c}0.39 * * * \\
(4.29)\end{array}$ \\
\hline Age $45-54$ & $\begin{array}{c}-0.43 * * * \\
(-6.75)\end{array}$ & $\begin{array}{c}0.73 * * * \\
(8.05)\end{array}$ & $\begin{array}{c}0.52^{* * *} \\
(5.67)\end{array}$ \\
\hline Age $55-64$ & $\begin{array}{c}-0.56^{* * *} \\
(-8.47)\end{array}$ & $\begin{array}{c}0.57 * * * \\
(6.21)\end{array}$ & $\begin{array}{c}0.73 * * * \\
(7.99)\end{array}$ \\
\hline Age $65-74$ & $\begin{array}{c}-0.58 * * * \\
(-6.99)\end{array}$ & $\begin{array}{c}0.65^{* * *} \\
(6.47)\end{array}$ & $\begin{array}{c}0.48^{* * *} \\
(4.82)\end{array}$ \\
\hline Age 75 or more & $\begin{array}{c}-0.42 * * * \\
(-2.71)\end{array}$ & $\begin{array}{l}-0.055 \\
(-0.28)\end{array}$ & $\begin{array}{l}0.28^{*} \\
(1.94)\end{array}$ \\
\hline Female & $\begin{array}{l}-0.031 \\
(-1.52)\end{array}$ & $\begin{array}{l}-0.024 \\
(-1.29)\end{array}$ & $\begin{array}{l}-0.013 \\
(-0.71)\end{array}$ \\
\hline Minority & $\begin{array}{c}0.27 * * * \\
(10.6)\end{array}$ & $\begin{array}{c}-0.055^{* *} \\
(-2.21)\end{array}$ & $\begin{array}{c}-0.30 * * * \\
(-12.0)\end{array}$ \\
\hline Some high school, but no diploma & $\begin{array}{l}0.31 * * \\
(2.39)\end{array}$ & $\begin{array}{c}0.77 * * * \\
(4.33)\end{array}$ & $\begin{array}{c}-0.55 * * * \\
(-3.84)\end{array}$ \\
\hline High school graduate & $\begin{array}{l}0.22^{*} \\
(1.82)\end{array}$ & $\begin{array}{c}0.95^{* * *} \\
(5.65)\end{array}$ & $\begin{array}{c}-0.15 \\
(-1.24)\end{array}$ \\
\hline Technical, trade, or vocational degree & $\begin{array}{l}0.041 \\
(0.33)\end{array}$ & $\begin{array}{c}0.96^{* * *} \\
(5.65)\end{array}$ & $\begin{array}{l}0.092 \\
(0.76)\end{array}$ \\
\hline Some college, but no degree & $\begin{array}{c}0.19 \\
(1.61)\end{array}$ & $\begin{array}{c}0.93^{* * * *} \\
(5.54)\end{array}$ & $\begin{array}{l}0.045 \\
(0.38)\end{array}$ \\
\hline Associate's degree & $\begin{array}{c}0.31 * * * \\
(2.59)\end{array}$ & $\begin{array}{c}1.01 * * * \\
(5.99)\end{array}$ & $\begin{array}{l}-0.026 \\
(-0.22)\end{array}$ \\
\hline Bachelor's degree & $\begin{array}{l}0.015 \\
(0.13)\end{array}$ & $\begin{array}{c}0.90^{* * *} \\
(5.34)\end{array}$ & $\begin{array}{c}0.32^{* * *} \\
(2.76)\end{array}$ \\
\hline Some graduate school, but no degree & $\begin{array}{c}0.16 \\
(1.31)\end{array}$ & $\begin{array}{c}1.07 * * * \\
(6.29)\end{array}$ & $\begin{array}{c}0.37 * * * \\
(3.09)\end{array}$ \\
\hline Master's degree & $\begin{array}{l}-0.042 \\
(-0.35)\end{array}$ & $\begin{array}{c}0.77 * * * \\
(4.58)\end{array}$ & $\begin{array}{c}0.47^{* * *} \\
(3.99)\end{array}$ \\
\hline Professional school or doctorate & $\begin{array}{c}-0.18 \\
(-1.45) \\
\end{array}$ & $\begin{array}{c}0.79 * * * \\
(4.66) \\
\end{array}$ & $\begin{array}{c}0.64 * * * \\
(5.31) \\
\end{array}$ \\
\hline Number of firms & 4601 & 4601 & 4601 \\
\hline
\end{tabular}




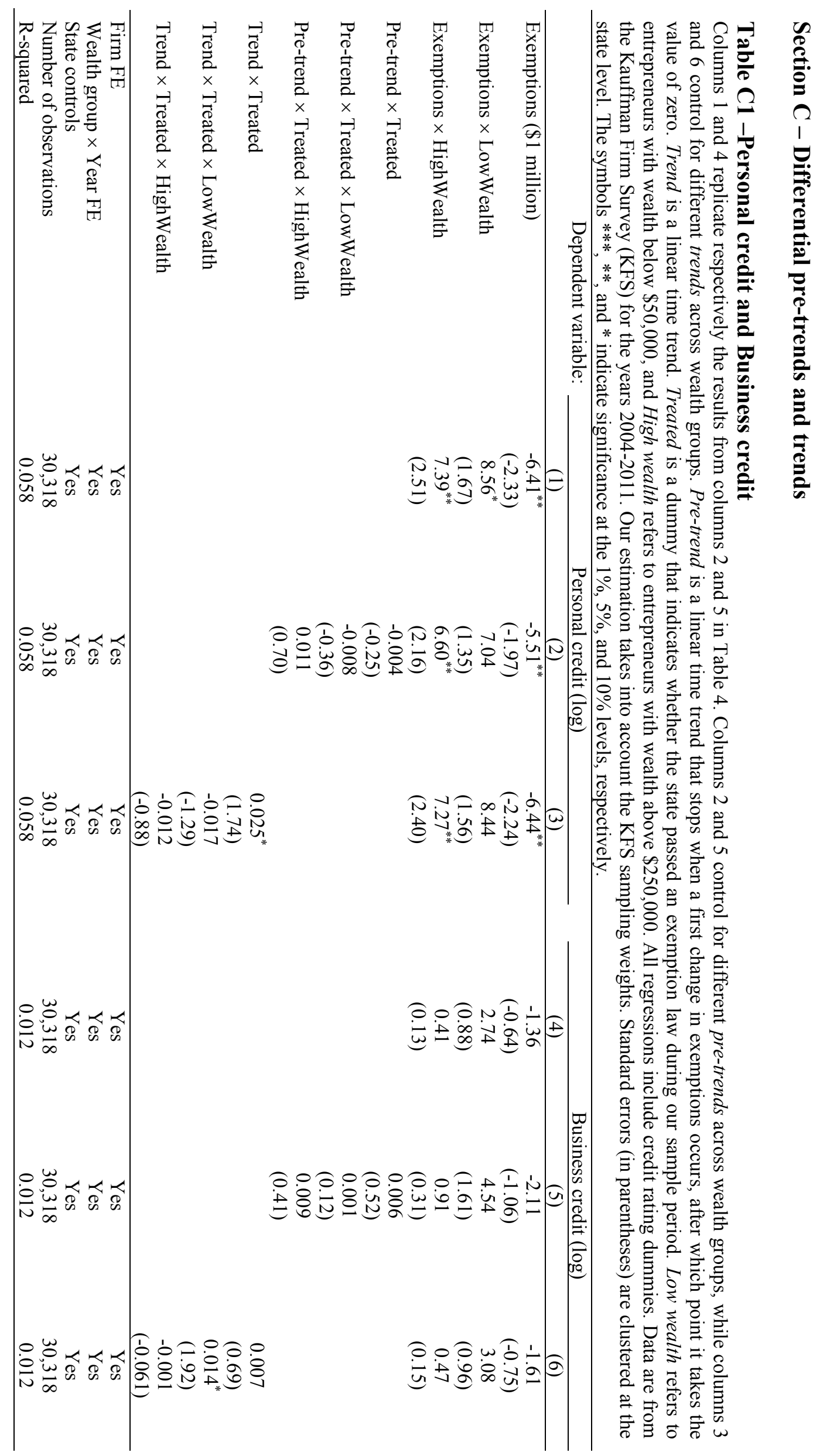




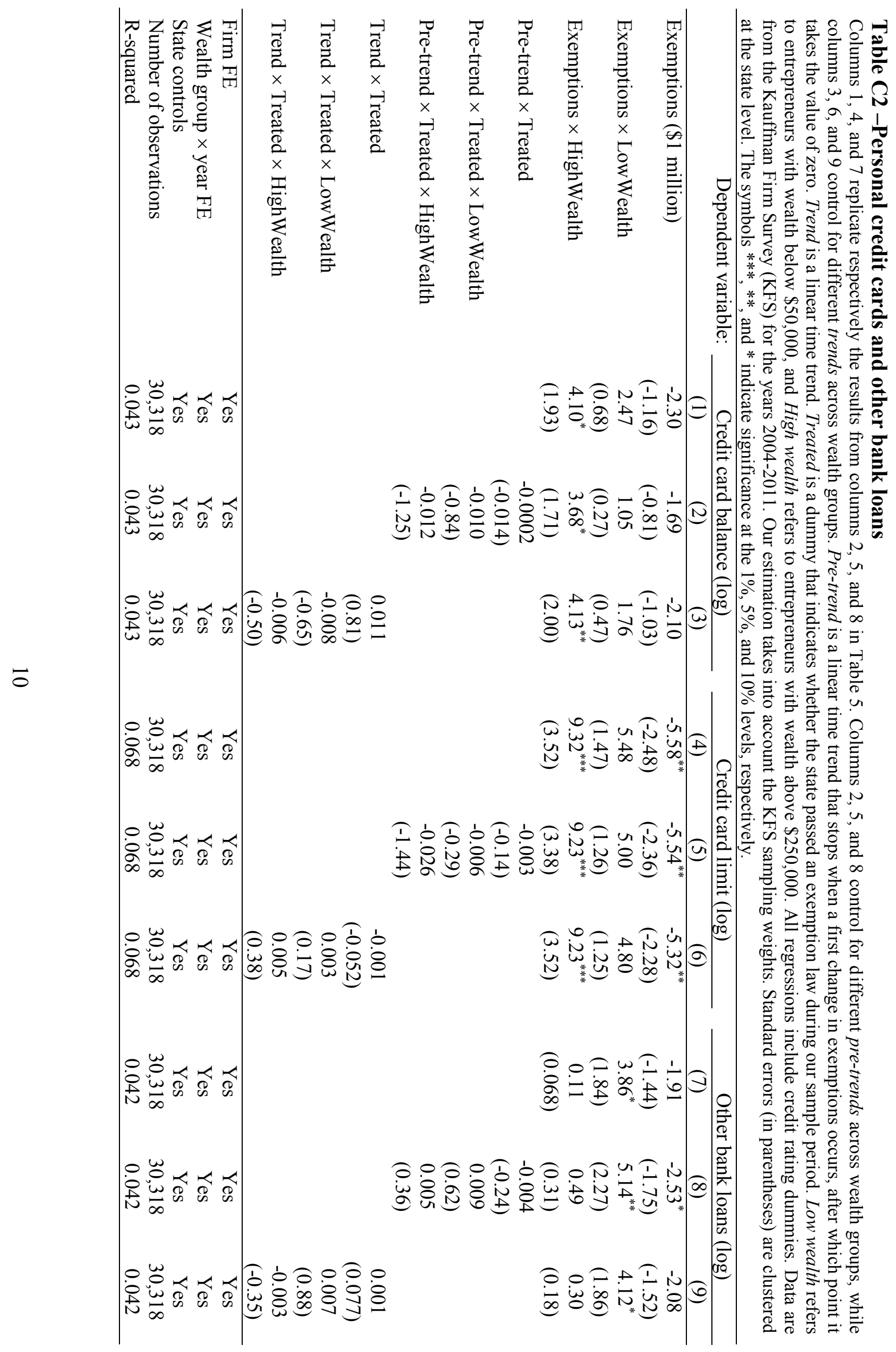




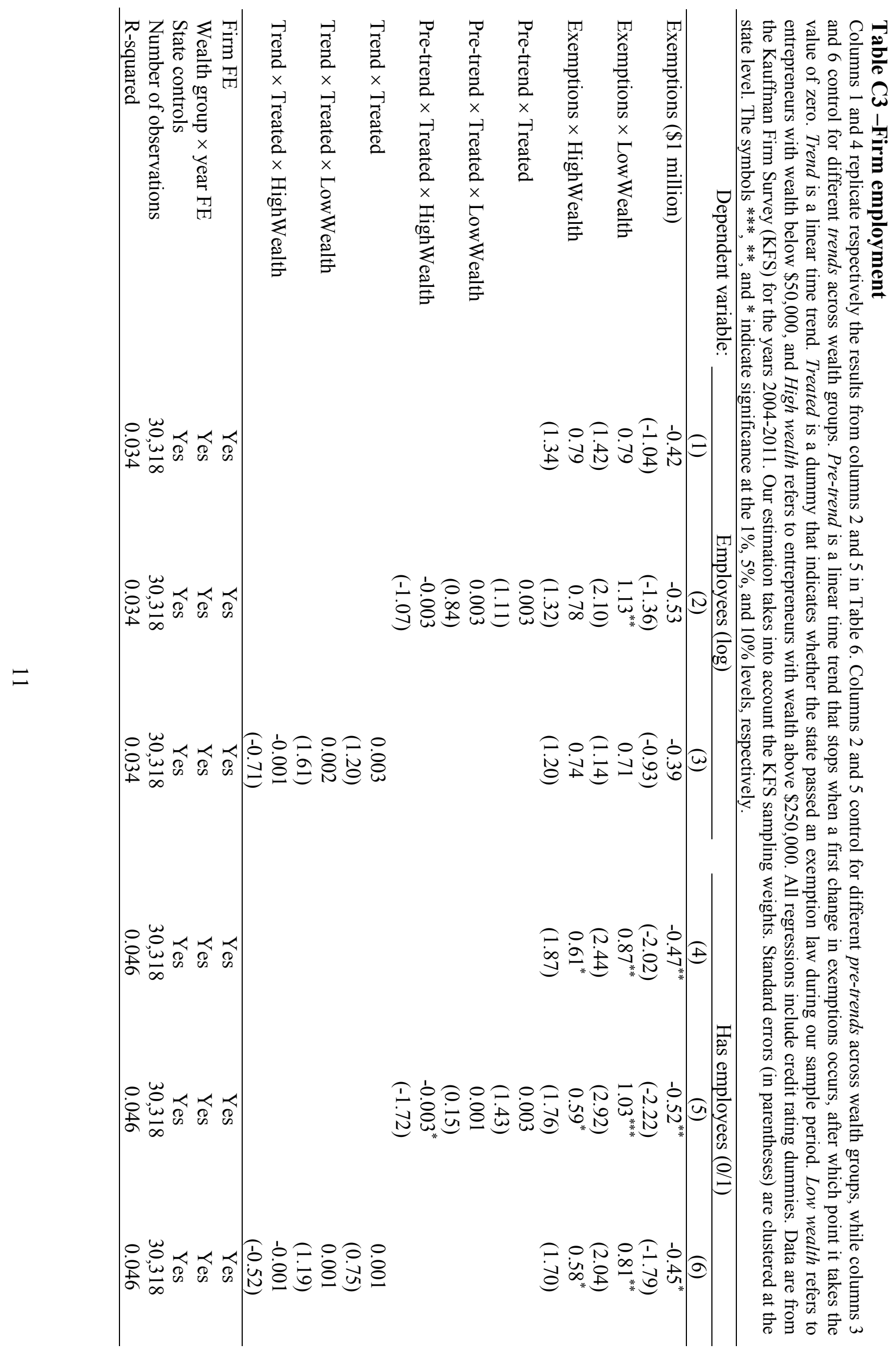




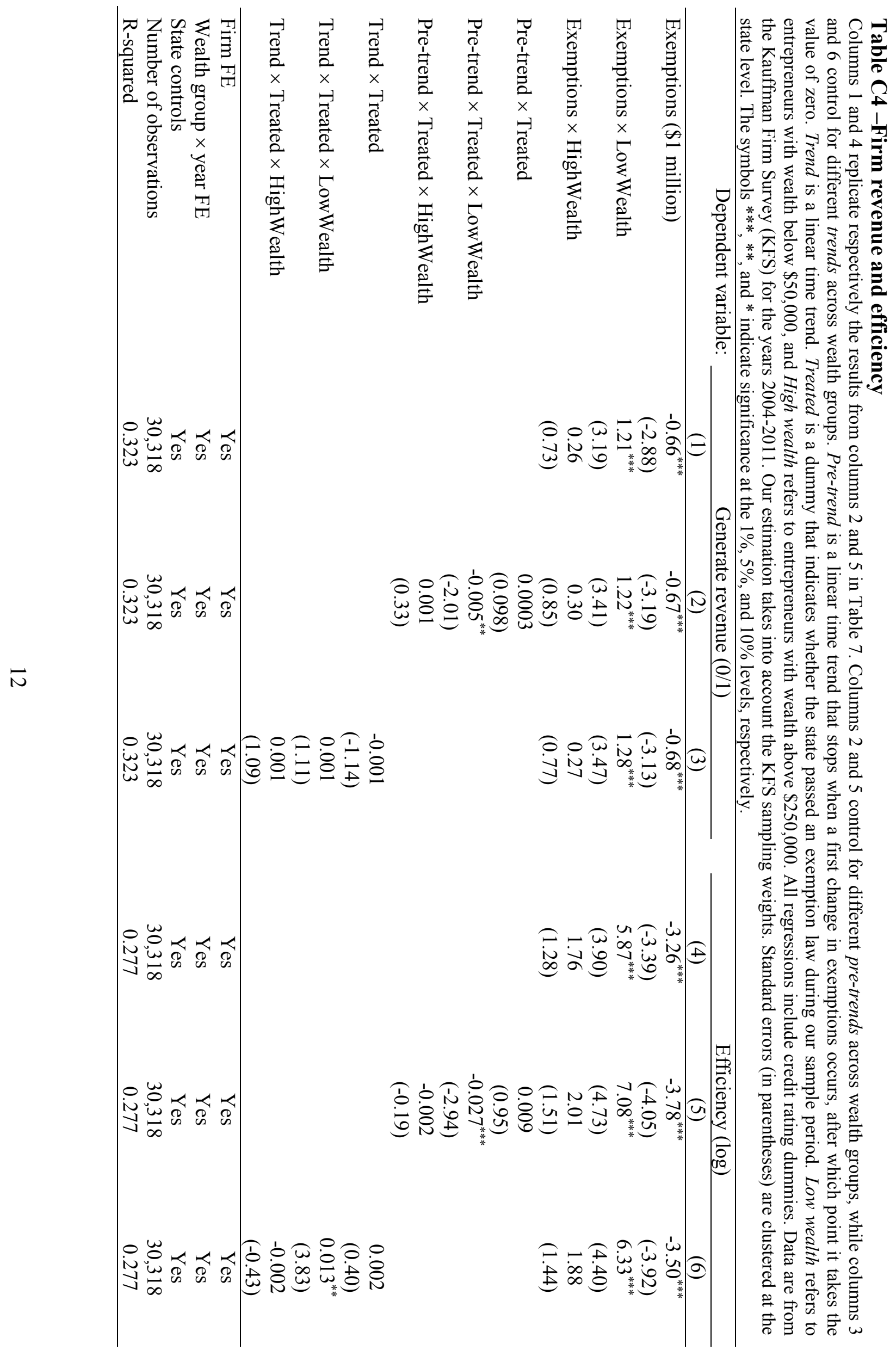




\section{Section D - Nonparametric standard errors}

Table D1 -Personal credit and Business credit

Columns 1 and 3 replicate respectively the results from columns 1 and 4 in Table 4, in which standard errors were clustered at the state level. Columns 2 and 4 re-estimate the regressions with jackknifed standard errors. Data are from the Kauffman Firm Survey (KFS) for the years 2004-2011. Our estimation takes into account the KFS sampling weights. The symbols $* * *, * *$, and * indicate significance at the $1 \%, 5 \%$, and $10 \%$ levels, respectively.

\begin{tabular}{|c|c|c|c|c|}
\hline \multirow{3}{*}{$\begin{array}{r}\text { Dependent variable: } \\
\text { Standard errors: }\end{array}$} & \multicolumn{2}{|c|}{ Personal credit $(\log )$} & \multicolumn{2}{|c|}{ Business credit (log) } \\
\hline & $(1)$ & $(2)$ & $(3)$ & $(4)$ \\
\hline & Clustered & Jackknifed & Clustered & Jackknifed \\
\hline \multicolumn{5}{|l|}{ Exemptions } \\
\hline \multirow[t]{2}{*}{ Exemptions (\$1 million) } & $-5.66^{* *}$ & $-5.66^{* *}$ & -2.20 & -2.20 \\
\hline & $(-2.08)$ & $(-2.06)$ & $(-1.12)$ & $(-1.04)$ \\
\hline \multirow{2}{*}{ Exemptions $\times$ LowWealth } & 7.38 & $7.38^{*}$ & 4.56 & 4.56 \\
\hline & $(1.48)$ & (1.69) & $(1.64)$ & $(1.55)$ \\
\hline \multirow{2}{*}{ Exemptions $\times$ HighWealth } & $6.60^{* *}$ & $6.60^{*}$ & 0.85 & 0.85 \\
\hline & $(2.20)$ & (1.94) & $(0.29)$ & $(0.30)$ \\
\hline Firm controls & $1.19^{* * *}$ & $1.19^{* * *}$ & $0.88^{* * *}$ & $0.88^{* * *}$ \\
\hline \multirow[t]{2}{*}{ Credit risk 1} & $(5.13)$ & $(5.02)$ & $(5.81)$ & $(4.20)$ \\
\hline & $0.98^{* * *}$ & $0.98^{* * *}$ & $0.48^{* * * *}$ & $0.48^{* * *}$ \\
\hline \multirow[t]{2}{*}{ Credit risk 2} & $(6.70)$ & $(7.43)$ & $(5.67)$ & $(5.10)$ \\
\hline & $0.81^{* * *}$ & $0.81^{* * *}$ & $0.41^{* * *}$ & $0.41^{* * *}$ \\
\hline \multirow[t]{2}{*}{ Credit risk 3} & $(7.35)$ & $(7.44)$ & $(6.68)$ & $(5.58)$ \\
\hline & $0.48^{* * *}$ & $0.48^{* * *}$ & $0.22^{* * *}$ & $0.22^{* *}$ \\
\hline \multirow[t]{2}{*}{ Credit risk 4} & $(4.21)$ & $(3.54)$ & $(3.83)$ & $(2.57)$ \\
\hline & -0.10 & -0.10 & 0.081 & 0.081 \\
\hline Credit risk 5 & $(-0.64)$ & $(-0.68)$ & $(0.89)$ & $(0.79)$ \\
\hline Firm FE & Yes & Yes & Yes & Yes \\
\hline Year FE & Yes & Yes & Yes & Yes \\
\hline State controls & Yes & Yes & Yes & Yes \\
\hline Number of observations & 30,318 & 30,318 & 30,318 & 30,318 \\
\hline R-squared & 0.058 & 0.058 & 0.011 & 0.011 \\
\hline
\end{tabular}




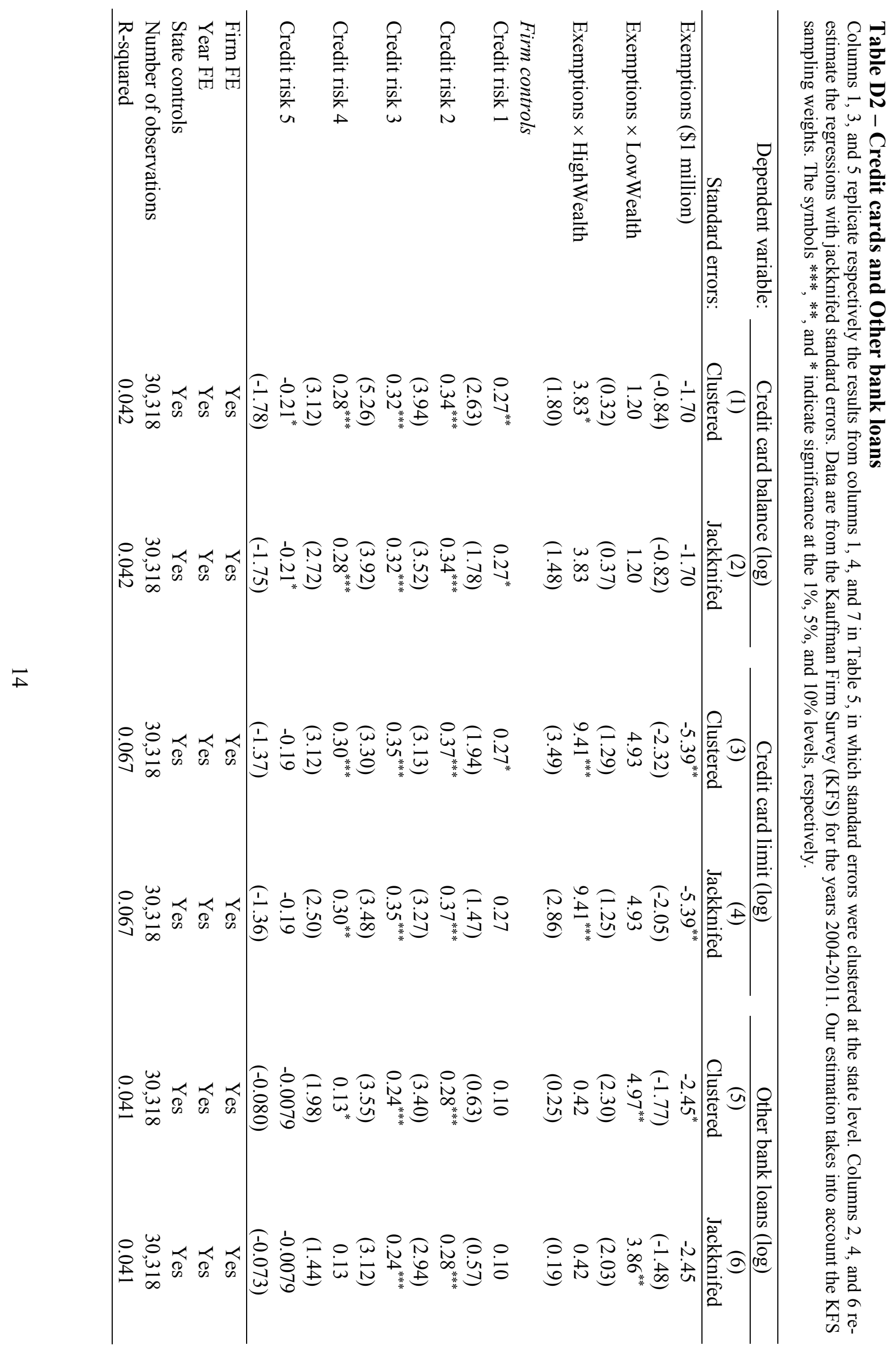


Table D3 - Firm employment

Columns 1 and 3 replicate respectively the results from columns 1 and 4 in Table 6, in which standard errors were clustered at the state level. Columns 2 and 4 re-estimate the regressions with jackknifed standard errors. Data are from the Kauffman Firm Survey (KFS) for the years 2004-2011. Our estimation takes into account the KFS sampling weights. The symbols $* * *, * *$, and * indicate significance at the $1 \%, 5 \%$, and $10 \%$ levels, respectively.

\begin{tabular}{|c|c|c|c|c|}
\hline \multirow{2}{*}{$\begin{array}{r}\text { Dependent variable: } \\
\text { Standard errors: }\end{array}$} & \multicolumn{2}{|c|}{ Employees (log) } & \multicolumn{2}{|c|}{ Has employees $(0 / 1)$} \\
\hline & $\begin{array}{c}\text { (1) } \\
\text { Clustered }\end{array}$ & $\begin{array}{c}(2) \\
\text { Jackknifed }\end{array}$ & $\begin{array}{c}3) \\
\text { Clustered }\end{array}$ & $\begin{array}{c}\text { (4) } \\
\text { Jackknifed }\end{array}$ \\
\hline \multicolumn{5}{|l|}{ Exemptions } \\
\hline Exemptions (\$1 million) & $\begin{array}{c}-0.49 \\
(-1.25)\end{array}$ & $\begin{array}{c}-0.49 \\
(-1.02)\end{array}$ & $\begin{array}{l}-0.51^{* *} \\
(-2.17)\end{array}$ & $\begin{array}{l}-0.51^{* *} \\
(-2.09)\end{array}$ \\
\hline Exemptions $\times$ LowWealth & $\begin{array}{c}1.01^{*} \\
(1.86)\end{array}$ & $\begin{array}{c}1.01 \\
(1.29)\end{array}$ & $\begin{array}{c}0.99^{* * * *} \\
(2.78)\end{array}$ & $\begin{array}{l}0.99^{* *} \\
(2.50)\end{array}$ \\
\hline Exemptions $\times$ HighWealth & $\begin{array}{c}0.77 \\
(1.31)\end{array}$ & $\begin{array}{c}0.77 \\
(1.28)\end{array}$ & $\begin{array}{c}0.60^{*} \\
(1.78)\end{array}$ & $\begin{array}{l}0.60^{*} \\
(1.92)\end{array}$ \\
\hline Firm controls & $0.27^{* * *}$ & $0.27^{* * *}$ & $0.14^{* * *}$ & $0.14^{* * *}$ \\
\hline Credit risk 1 & $\begin{array}{l}(9.24) \\
0.19^{* * *}\end{array}$ & $\begin{array}{l}(7.63) \\
0.19^{* * *}\end{array}$ & $\begin{array}{l}(8.97) \\
0.10^{* * *}\end{array}$ & $\begin{array}{l}(7.17) \\
0.10^{* * *}\end{array}$ \\
\hline Credit risk 2 & $\begin{array}{l}(9.42) \\
0.12^{* * *}\end{array}$ & $\begin{array}{l}(9.26) \\
0.12^{* * *}\end{array}$ & $\begin{array}{c}(9.16) \\
0.066^{* * *}\end{array}$ & $\begin{array}{c}(8.35) \\
0.066^{* * *}\end{array}$ \\
\hline Credit risk 3 & $\begin{array}{c}(7.43) \\
0.082^{* * *}\end{array}$ & $\begin{array}{c}(6.76) \\
0.082^{* * *}\end{array}$ & $\begin{array}{c}(7.31) \\
0.048^{* * *}\end{array}$ & $\begin{array}{c}(6.10) \\
0.048^{* * *}\end{array}$ \\
\hline Credit risk 4 & $\begin{array}{c}(4.44) \\
0.00081\end{array}$ & $\begin{array}{c}(4.05) \\
0.00081\end{array}$ & $\begin{array}{c}(3.71) \\
0.012\end{array}$ & $\begin{array}{l}(3.69) \\
0.012\end{array}$ \\
\hline Credit risk 5 & $(0.046)$ & $(0.031)$ & $(1.06)$ & $(0.80)$ \\
\hline Firm FE & Yes & Yes & Yes & Yes \\
\hline Year FE & Yes & Yes & Yes & Yes \\
\hline State controls & Yes & Yes & Yes & Yes \\
\hline Number of observations & 30,318 & 30,318 & 30,318 & 30,318 \\
\hline R-squared & 0.033 & 0.033 & 0.045 & 0.045 \\
\hline
\end{tabular}


Table D4 - Firm revenue and efficiency

Columns 1 and 3 replicate respectively the results from columns 1 and 4 in Table 7, in which standard errors were clustered at the state level. Columns 2 and 4 re-estimate the regressions with jackknifed standard errors. Data are from the Kauffman Firm Survey (KFS) for the years 2004-2011. Our estimation takes into account the KFS sampling weights. The symbols ***, **, and * indicate significance at the $1 \%, 5 \%$, and $10 \%$ levels, respectively.

\begin{tabular}{|c|c|c|c|c|}
\hline \multirow{3}{*}{$\begin{array}{r}\text { Dependent variable: } \\
\text { Standard errors: }\end{array}$} & \multicolumn{2}{|c|}{ Generate revenue $(0 / 1)$} & \multicolumn{2}{|c|}{ Efficiency (log) } \\
\hline & $(1)$ & $(2)$ & (3) & (4) \\
\hline & Clustered & Jackknifed & Clustered & Jackknifed \\
\hline \multicolumn{5}{|l|}{ Exemptions } \\
\hline \multirow[t]{2}{*}{ Exemptions ( $\$ 1$ million) } & $-0.73^{* * *}$ & $-0.73^{* * *}$ & $-4.08^{* * *}$ & $-4.08^{* * *}$ \\
\hline & $(-3.55)$ & $(-3.30)$ & $(-4.37)$ & $(-4.20)$ \\
\hline \multirow{2}{*}{ Exemptions $\times$ LowWealth } & $1.36^{* * *}$ & $1.36^{* * *}$ & $7.69^{* * *}$ & $7.69^{* * *}$ \\
\hline & $(3.88)$ & $(3.78)$ & $(5.06)$ & $(5.05)$ \\
\hline \multirow[t]{2}{*}{ Exemptions $\times$ HighWealth } & 0.33 & 0.33 & 2.18 & $2.18^{*}$ \\
\hline & $(0.96)$ & $(1.18)$ & $(1.64)$ & $(1.85)$ \\
\hline Firm controls & $0.094^{* * *}$ & $0.094^{* * *}$ & $0.42^{* * *}$ & $0.42^{* * *}$ \\
\hline \multirow[t]{2}{*}{ Credit risk 1} & $(5.29)$ & $(4.77)$ & $(4.93)$ & $(4.66)$ \\
\hline & $0.067^{* * *}$ & $0.067^{* * *}$ & $0.29^{* * *}$ & $0.29^{* * *}$ \\
\hline \multirow[t]{2}{*}{ Credit risk 2} & $(5.76)$ & $(5.27)$ & $(6.14)$ & $(5.74)$ \\
\hline & $0.058^{* * *}$ & $0.058^{* * * *}$ & $0.27^{* * *}$ & $0.27^{* * *}$ \\
\hline \multirow[t]{2}{*}{ Credit risk 3} & $(6.10)$ & $(5.32)$ & $(7.32)$ & $(6.48)$ \\
\hline & $0.055^{* * *}$ & $0.055^{* * *}$ & $0.16^{* * *}$ & $0.16^{* * *}$ \\
\hline \multirow[t]{2}{*}{ Credit risk 4} & $(6.55)$ & $(4.09)$ & $(4.39)$ & $(3.11)$ \\
\hline & $0.047^{* * *}$ & $0.047^{* * *}$ & $0.21^{* * *}$ & $0.21^{* * *}$ \\
\hline Credit risk 5 & $(3.04)$ & $(3.19)$ & $(3.97)$ & $(3.65)$ \\
\hline Firm FE & Yes & Yes & Yes & Yes \\
\hline Year FE & Yes & Yes & Yes & Yes \\
\hline State controls & Yes & Yes & Yes & Yes \\
\hline Number of observations & 30,318 & 30,318 & 30,318 & 30,318 \\
\hline R-squared & 0.323 & 0.323 & 0.277 & 0.277 \\
\hline
\end{tabular}




\section{Table D5 - Firm survival}

Column 1 replicates the results from Table 8, in which standard errors were clustered at the state level. Column 2 re-estimate the regression with jackknifed standard errors. Data are from the Kauffman Firm Survey (KFS) for the years 20042011. Our estimation takes into account the KFS sampling weights. The symbols $* * *, * *$, and $*$ indicate significance at the $1 \%, 5 \%$, and $10 \%$ levels, respectively.

\begin{tabular}{lcc}
\hline \multicolumn{1}{c}{ Dependent variable: } & \multicolumn{2}{c}{ Bankruptcy $(0 / 1)$} \\
\cline { 2 - 3 } Standard errors: & Clustered & Jackknifed \\
\hline Exemptions & & \\
Exemptions (\$1 million) & $2.75^{* * *}$ & $2.75^{* *}$ \\
& $(2.87)$ & $(2.00)$ \\
Exemptions $\times$ LowWealth & $-2.86^{*}$ & -2.86 \\
& $(-1.80)$ & $(-1.38)$ \\
Exemptions $\times$ HighWealth & $-2.09^{*}$ & -2.09 \\
& $(-1.66)$ & $(-1.14)$ \\
Firm controls & & \\
Credit risk 1 & & \\
& $-1.87^{* * *}$ & $-1.87^{* * *}$ \\
Credit risk 2 & $(-11.8)$ & $(-8.61)$ \\
& $-1.40^{* * *}$ & $-1.40^{* * *}$ \\
Credit risk 3 & $(-15.0)$ & $(-15.8)$ \\
& $-0.98^{* * *}$ & $-0.98^{* * *}$ \\
Credit risk 4 & $(-16.6)$ & $(-15.1)$ \\
& $-0.83^{* * *}$ & $-0.83^{* * *}$ \\
Credit risk 5 & $(-12.9)$ & $(-9.59)$ \\
& $-0.46^{* * *}$ & $-0.46^{* * *}$ \\
& $(-5.50)$ & $(-5.24)$ \\
State fixed effects & & \\
State controls & Yes & Yes \\
Owner controls & Yes & Yes \\
Number of observations & Yes & Yes \\
\hline & Yes & Yes \\
& 30,318 & 30,318 \\
\hline & &
\end{tabular}




\section{Section $E$ - The role of firm age}

\section{Table E1 -Personal credit and Business credit}

The table displays coefficients from panel regressions of the log of one plus the dollar amounts of Personal credit and Business credit. Age $<4$ and Age $\geq 4$ indicate respectively whether the observation is before or after 2008. Data are from the Kauffman Firm Survey (KFS) for the years 2004-2011. Our estimation takes into account the KFS sampling weights. Standard errors (in parentheses) are clustered at the state level. The symbols $* * *, * *$, and $*$ indicate significance at the $1 \%, 5 \%$, and $10 \%$ levels, respectively.

\begin{tabular}{lccc}
\hline \multirow{2}{*}{ Dependent variable: } & $\begin{array}{c}\text { Personal credit } \\
(\mathrm{log})\end{array}$ & & $\begin{array}{c}\text { Business credit } \\
(\mathrm{log})\end{array}$ \\
Exemptions & $(1)$ & $(2)$ \\
Exemptions $\times($ Age $<4)$ & $-7.49^{* *}$ & \\
Exemptions $\times($ Age $\geq 4)$ & $(-2.59)$ & 1.58 \\
Exemptions $\times$ LowWealth $\times($ Age $<4)$ & $-5.17^{*}$ & $(0.81)$ \\
& $(-1.92)$ & -2.89 \\
Exemptions $\times$ LowWealth $\times($ Age $\geq 4)$ & $10.94^{* *}$ & $(-1.38)$ \\
& $(2.15)$ & -0.66 \\
Exemptions $\times$ HighWealth $\times($ Age $<4)$ & 6.60 & $(-0.21)$ \\
Exemptions $\times$ HighWealth $\times($ Age $\geq 4)$ & $(1.35)$ & $5.51^{*}$ \\
& 6.21 & $(1.89)$ \\
& $(1.52)$ & -3.41 \\
Credit rating Dummies & $6.60^{* *}$ & $(-1.35)$ \\
Firm FE & $(2.17)$ & 1.51 \\
Year FE & & $(0.50)$ \\
State controls & Yes & \\
Number of observations & Yes & Yes \\
R-squared & No & Yes \\
\hline
\end{tabular}




\section{Table F1 - Personal credit and Business credit}

The table replicates the results in Table 4 using reported wealth (Columns 1 and 3) and predicted wealth for the overlapping sample (Columns 2 and 4). Appendix B provides details on the wealth measures. Data are from the Kauffman Firm Survey (KFS) for the years 2004-2011. Wealth is reported in the KFS for the first time in 2008 (fourth follow-up survey). Our estimation takes into account the KFS sampling weights. The symbols $* * *, * *$, and $*$ indicate significance at the $1 \%, 5 \%$, and $10 \%$ levels, respectively.

\begin{tabular}{lcccccc}
\hline \multicolumn{1}{c}{ Dependent variable: } & \multicolumn{2}{c}{ Personal credit $(\log )$} & & \multicolumn{2}{c}{ Business credit $(\log )$} \\
\cline { 2 - 3 } \cline { 5 - 6 } \multicolumn{1}{c}{ Wealth measure: } & Reported & Predicted & & $(3)$ & Reported & Predicted \\
\hline Exemptions (\$1 million) & $-6.95^{* * *}$ & $-5.44^{* *}$ & & -0.59 & 0.42 \\
& $(-3.21)$ & $(-2.11)$ & & $(-0.41)$ & $(0.22)$ \\
Exemptions $\times$ LowWealth & $9.10^{* * *}$ & 7.19 & & 0.40 & 0.19 \\
& $(3.19)$ & $(1.30)$ & & $(0.28)$ & $(0.08)$ \\
Exemptions $\times$ HighWealth & $7.49^{* * *}$ & $5.81^{* *}$ & & -0.15 & -1.75 \\
& $(3.07)$ & $(2.31)$ & & $(-0.08)$ & $(-0.59)$ \\
& & & & & \\
\hline Firm FE & Yes & Yes & & Yes & Yes \\
Credit rating dummies & Yes & Yes & & Yes & Yes \\
Wealth group $\times$ Year FE & Yes & Yes & & Yes & Yes \\
State controls & Yes & Yes & & Yes & Yes \\
Number of observations & 20,829 & 19,617 & & 20,829 & 19,617 \\
R-squared & 0.036 & 0.035 & & 0.01 & 0.01 \\
\hline
\end{tabular}




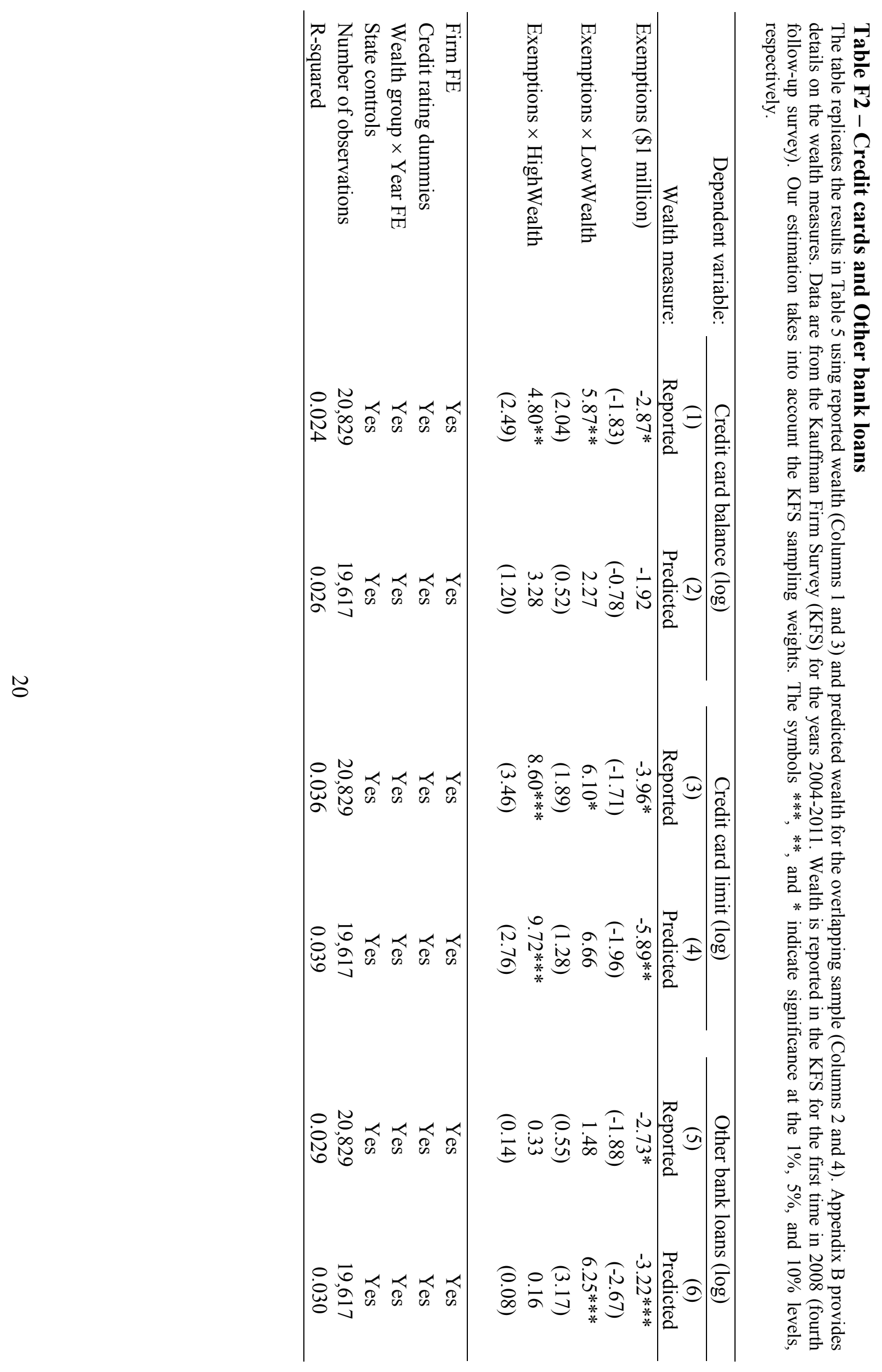




\section{Table F3 - Firm employment}

The table replicates the results in Table 6 using reported wealth (Columns 1 and 3) and predicted wealth for the overlapping sample (Columns 2 and 4). Appendix B provides details on the wealth measures. Data are from the Kauffman Firm Survey (KFS) for the years 2004-2011. Wealth is reported in the KFS for the first time in 2008 (fourth follow-up survey). Our estimation takes into account the KFS sampling weights. The symbols $* * *, * *$, and $*$ indicate significance at the $1 \%, 5 \%$, and $10 \%$ levels, respectively.

\begin{tabular}{|c|c|c|c|c|}
\hline \multirow{2}{*}{$\begin{array}{r}\text { Dependent variable: } \\
\text { Wealth measure: }\end{array}$} & \multicolumn{2}{|c|}{ Employees $(\log )$} & \multicolumn{2}{|c|}{ Has employees $(0 / 1)$} \\
\hline & $\begin{array}{c}\text { (1) } \\
\text { Reported }\end{array}$ & $\begin{array}{c}(2) \\
\text { Predicted }\end{array}$ & $\begin{array}{c}\text { (3) } \\
\text { Reported }\end{array}$ & $\begin{array}{c}(4) \\
\text { Predicted }\end{array}$ \\
\hline Exemptions ( $\$ 1$ million) & $\begin{array}{l}-0.65^{*} \\
(-1.88)\end{array}$ & $\begin{array}{c}-0.27 \\
(-0.79)\end{array}$ & $\begin{array}{l}-0.51^{*} \\
(-1.84)\end{array}$ & $\begin{array}{c}-0.44 * * \\
(-1.97)\end{array}$ \\
\hline Exemptions $\times$ LowWealth & $\begin{array}{c}0.76 \\
(1.49)\end{array}$ & $\begin{array}{c}0.48 \\
(1.04)\end{array}$ & $\begin{array}{c}0.73 * * \\
(1.96)\end{array}$ & $\begin{array}{l}0.86^{* *} \\
(2.55)\end{array}$ \\
\hline Exemptions $\times$ HighWealth & $\begin{array}{l}1.35^{* *} \\
(2.26)\end{array}$ & $\begin{array}{c}0.29 \\
(0.83)\end{array}$ & $\begin{array}{c}0.96 * * * \\
(2.67)\end{array}$ & $\begin{array}{c}0.36 \\
(1.30)\end{array}$ \\
\hline Firm FE & Yes & Yes & Yes & Yes \\
\hline Credit rating dummies & Yes & Yes & Yes & Yes \\
\hline Wealth group $\times$ Year FE & Yes & Yes & Yes & Yes \\
\hline State controls & Yes & Yes & Yes & Yes \\
\hline Number of observations & 20,829 & 19,617 & 20,829 & 19,617 \\
\hline R-squared & 0.049 & 0.045 & 0.044 & 0.041 \\
\hline
\end{tabular}




\section{Table F4 - Firm revenue and efficiency}

The table replicates the results in Table 7 using reported wealth (Columns 1 and 3) and predicted wealth for the overlapping sample (Columns 2 and 4). Appendix B provides details on the wealth measures. Data are from the Kauffman Firm Survey (KFS) for the years 2004-2011. Wealth is reported in the KFS for the first time in 2008 (fourth follow-up survey). Our estimation takes into account the KFS sampling weights. The symbols $* * *, * *$, and * indicate significance at the $1 \%, 5 \%$, and $10 \%$ levels, respectively.

\begin{tabular}{lcccccc}
\hline \multirow{2}{*}{ Dependent variable: } & \multicolumn{2}{c}{ Generates revenue } & & \multicolumn{2}{c}{ Efficiency } \\
\cline { 2 - 3 } \cline { 5 - 6 } Wealth measure: & Reported & Predicted & & $(3)$ & Reported & Predicted \\
\hline Exemptions (\$1 million) & $-0.43^{* *}$ & $-0.28^{*}$ & & $-1.41^{*}$ & $-1.62^{*}$ \\
& $(-2.42)$ & $(-1.73)$ & & $(-1.86)$ & $(-1.91)$ \\
Exemptions $\times$ LowWealth & 0.35 & $0.70^{* *}$ & & 0.98 & $3.72^{* * *}$ \\
& $(1.07)$ & $(2.59)$ & & $(0.66)$ & $(3.09)$ \\
Exemptions $\times$ HighWealth & -0.06 & -0.29 & & -0.11 & -0.45 \\
& $(-0.25)$ & $(-1.07)$ & & $(-0.11)$ & $(-0.37)$ \\
& & & & & \\
\hline Firm FE & Yes & Yes & & Yes & Yes \\
Credit rating dummies & Yes & Yes & & Yes & Yes \\
Wealth group $\times$ Year FE & Yes & Yes & & Yes & Yes \\
State controls & Yes & Yes & & Yes & Yes \\
Number of observations & 20,829 & 19,617 & & 20,829 & 19,617 \\
R-squared & 0.447 & 0.448 & & 0.401 & 0.395 \\
\hline
\end{tabular}




\section{Table F5 - Firm failure}

The table replicates the results in Table 8 using reported wealth (Columns 1 and 3) and predicted wealth for the overlapping sample (Columns 2 and 4). Appendix B provides details on the wealth measures. Data are from the Kauffman Firm Survey (KFS) for the years 2004-2011. Wealth is reported in the KFS for the first time in 2008 (fourth follow-up survey). Our estimation takes into account the KFS sampling weights. The symbols ***,**, and * indicate significance at the $1 \%, 5 \%$, and $10 \%$ levels, respectively.

\begin{tabular}{lcc}
\hline \multirow{2}{*}{ Dependent variable: } & \multicolumn{2}{c}{ Bankrupt $(0 / 1)$} \\
\cline { 2 - 3 } Wealth measure: & Reported & Predicted \\
\hline Exemptions ( $\$$ 1 million) & $8.18^{* *}$ & $5.36^{*}$ \\
& $(2.44)$ & $(1.80)$ \\
Exemptions $\times$ LowWealth & -1.19 & -4.35 \\
& $(-0.52)$ & $(-1.22)$ \\
Exemptions $\times$ HighWealth & -0.71 & -1.92 \\
& $(-0.46)$ & $(-0.67)$ \\
& & \\
\hline Firm FE & Yes & Yes \\
Credit rating dummies & Yes & Yes \\
Wealth group $\times$ Year FE & Yes & Yes \\
State controls & Yes & Yes \\
Number of observations & 20,829 & 19,617 \\
R-squared & 0.171 & 0.164 \\
\hline
\end{tabular}




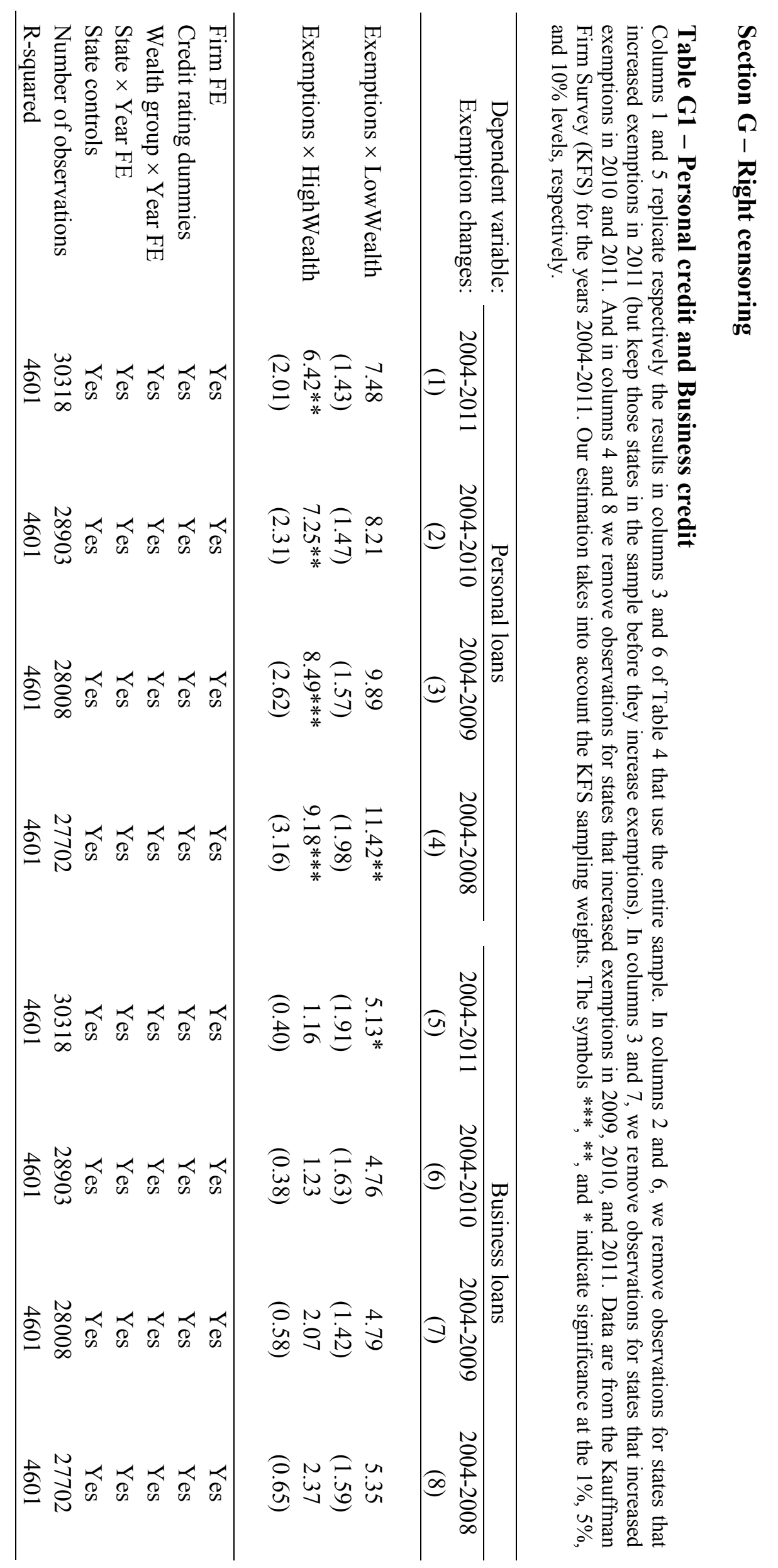

